
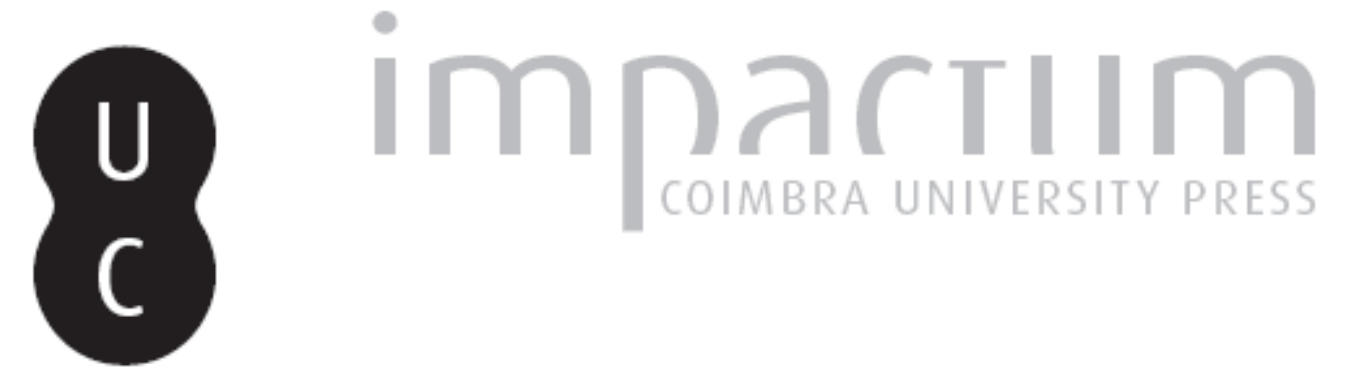

O Visconde de Vila Maior: alguns apontamentos sobre a sua vida e ação

Autor(es): Mota, Guilhermina

Publicado por: Faculdade de Letras da Universidade de Coimbra

URL persistente:

URI:http://hdl.handle.net/10316.2/32302

DOI:

DOI:http://dx.doi.org/10.14195/0870-4112_10_10

Accessed : $\quad$ 26-Apr-2023 09:46:08

A navegação consulta e descarregamento dos títulos inseridos nas Bibliotecas Digitais UC Digitalis, UC Pombalina e UC Impactum, pressupõem a aceitação plena e sem reservas dos Termos e Condições de Uso destas Bibliotecas Digitais, disponíveis em https://digitalis.uc.pt/pt-pt/termos.

Conforme exposto nos referidos Termos e Condições de Uso, o descarregamento de títulos de acesso restrito requer uma licença válida de autorização devendo o utilizador aceder ao(s) documento(s) a partir de um endereço de IP da instituição detentora da supramencionada licença.

Ao utilizador é apenas permitido o descarregamento para uso pessoal, pelo que o emprego do(s) título(s) descarregado(s) para outro fim, designadamente comercial, carece de autorização do respetivo autor ou editor da obra.

Na medida em que todas as obras da UC Digitalis se encontram protegidas pelo Código do Direito de Autor e Direitos Conexos e demais legislação aplicável, toda a cópia, parcial ou total, deste documento, nos casos em que é legalmente admitida, deverá conter ou fazer-se acompanhar por este aviso. 

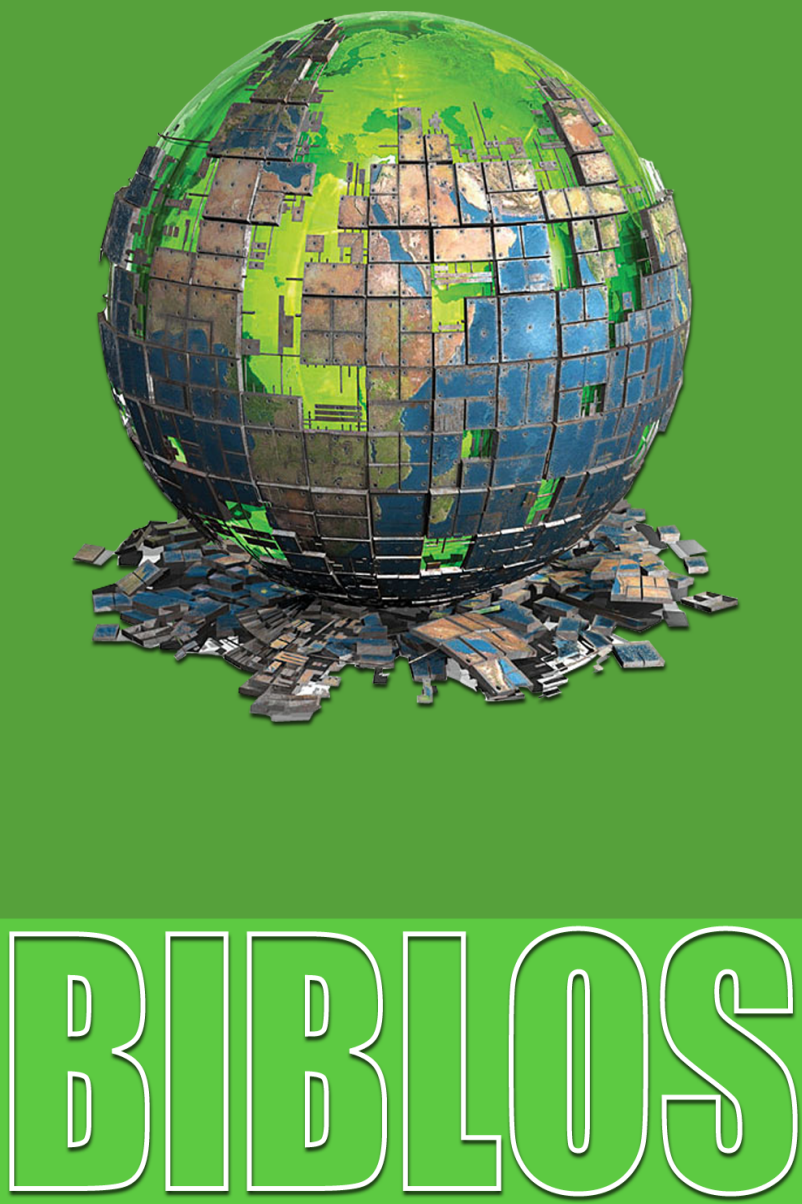

$\frac{\text { REVISTA DA FACULDADE DE LETRAS }}{\text { UNIVERSIDADE DE COIMBRA }}$ 
Biblos, n. s. X (2012) $\ldots-\ldots$

Guilhermina Mota

Faculdade de Letras da Universidade de Coimbra Centro de Estudos da População, Economia e Sociedade

\section{O VISCONDE DE VILA MAIOR: \\ alguns apontamentos sobre a sua vida e ação*}

\section{Resumo}

O Visconde de Vila Maior, Júlio Máximo de Oliveira Pimentel (1809-1884), académico, político e cidadão, notabilizou-se sobretudo na área da Química, quer como professor na Escola Politécnica de Lisboa, quer como cientista rigoroso e infatigável, empenhando-se também na aplicação prática da ciência à indústria e à agricultura. Este trabalho traz à luz a sua preparação científica, incidindo na sua estada em Paris como bolseiro, entre 1844 e 1846 - frequentando os cursos dos mestres mais notáveis da época e exercitando-se na prática de laboratório -, nas viagens de estudo que empreendeu - visitando não só instalações universitárias, mas também uma série de unidades industriais de ponta, informando-se sobre matérias-primas, métodos de fabricação e maquinaria utilizada -, e nos estudos realizados aquando da sua participação na Exposição Universal de Paris de 1855. A preparação científica que efetuou no estrangeiro foi colocada ao serviço do país, na sua docência e investigação, em pareceres e comissões, em atividades empresariais, nas suas publicações, muitas destinadas ao grande público.

Palavras-Chave: ...

Abstract

Keywords: ...

* Este trabalho foi desenvolvido no âmbito do projeto "A história da Botânica na Universidade de Coimbra e a sua expressão no mundo lusófono: de Brotero a Abílio Fernandes", da Faculdade de Ciências e Tecnologia da Universidade de Coimbra, financiado pela Fundação para a Ciência e Tecnologia (Projeto HC/0064/2009). 
«O fim das sciencias é naturalmente utilitario; o seu ultimo rezultado é a applicação dos descubrimentos humanos ao serviço da communidade» ${ }^{1}$. Estas palavras do Visconde de Vila Maior sintetizam o seu pensamento sobre a função das ciências e a utilidade da pesquisa científica. Homem de ciência, movia-se num universo racionalista, confiante nas conquistas que o saber ia trazendo, mas também, liberal convicto e cidadão empenhado, entendia que as aquisições do conhecimento deviam ser usadas em benefício do ser coletivo, da evolução do país, do bem-estar das populações. A sua vida e o seu trabalho, desenvolvido sobretudo na área da Química, foram norteados por essa matriz ideológica.

No século XIX, havia a nítida perceção de que as novas descobertas científicas, através de soluções práticas e concretas, estavam na base do progresso que a humanidade conhecia, existindo uma estreita interdependência entre investigação aplicada, inovação técnica e desenvolvimento social. E, entre as ciências do século, a Química tinha um lugar cimeiro, sobretudo pela sua ligação com a economia ao possibilitar uma utilização nova das riquezas do planeta, as matérias-primas, transformadas pelo espírito científico, como o expressa Vila Maior de forma incisiva: «Entre os homens que teem reflectido, por pouco que seja, sobre as causas da civilisação actual, não ha por certo um só que desconheça a vasta importancia da chimica moderna, o seu grande influxo e amplissima ascendencia sobre quasi todos os ramos das sciencias naturaes, e, principalmente, sobre o trabalho industrial, ou elle tenha por fim augmentar e aperfeiçoar as producções agricolas, ou transformar a materia inerte em coisas uteis» ${ }^{2}$.

O Liberalismo trouxe novas estruturas e novos homens: nas preferências para cargos políticos e administrativos, deixou de pesar tanto o sangue, pesando mais o merecimento, embora tendência para imitar os antigos costumes transpareça da copiosa produção de barões e de viscondes. Trouxe também grandes melhoramentos de ordem material, para incremento dos quais se tornavam imprescindíveis pessoas bem preparadas científica e tecnicamente. A elas foram pois confiadas as reformas mais diversas.

${ }^{1}$ J. Pimentel, "Palestra scientifica", in Revista Contemporanea de Portugal e Brazil, Lisboa: Typographia do Futuro, primeiro anno, 1859, p. 128.

2 Ibidem, p. 188. 


\section{Intervenção na esfera política e administrativa}

O Visconde de Vila Maior ${ }^{3}$ representa de forma clara a nova era do Liberalismo, pois conjugou a sua carreira de professor e de cientista com a atividade política e administrativa, com uma participação na vida económica, com um forte envolvimento cívico e associativo ${ }^{4}$.

Bacharel formado em Matemática pela Universidade de Coimbra, foi lente da cadeira de Química da Escola Politécnica de Lisboa, professor de Química do Instituto Industrial de Lisboa (1854-1858), diretor do Instituto Agrícola e Escola Regional de Lisboa (1857-1864), reitor da Universidade de Coimbra, cargo que ocupou desde 1869 até à sua morte em 1884, o que acabou por se traduzir num longo reitorado apesar do frio acolhimento que o corpo universitário lhe dispensou ${ }^{5}$. Frio acolhimento que é compreensível, uma vez que ele não só não era professor da Universidade, como provinha de uma das novas escolas, a Escola Politécnica de Lisboa, que tinha retirado alunos às Faculdades de Matemática e de Filosofia ${ }^{6}$. Além disso, propusera anos antes uma

${ }^{3}$ Da bibliografia existente sobre este importante académico e cientista, destaco: J. M. Latino Coelho, "Julio Máximo de Oliveira Pimentel", in Revista Contemporanea de Portugal e Brazil, cit., segundo anno, 1860, p. 439-455 e 559-570 e terceiro anno, 1861, p. 11-17. Júlio Augusto Henriques, "Visconde de Villa Maior", in Jornal de Horticultura Prática, vol. XVI, 1885, p. VII-XIV. Francisco Manuel Alves, Reitor de Baçal, Memorias arqueologico-historicas do distrito de Bragança, vol. VII, Os notaveis, Porto: Tipografia da Emprêsa Guedes, 1931, p. 406-410. Luís A. de Oliveira Ramos, "Um especialista do Douro: o Visconde de Vila Maior", in Douro - Estudos \& Documentos. Porto, vol. VI (11), 2001, p. 11-14. Isabel Cruz, "Preparadores de Química da Escola Politécnica (1837-1856)", in Atalaia (Intermundos), n. ${ }^{\text {ss }} 10-11,2002$, p. 177-196.

${ }^{4} \mathrm{O}$ mesmo acontecendo com outros químicos, como José Júlio Bettencourt Rodrigues. Ver Ana Cardoso de Matos, "Entre o laboratório, a indústria e a intervenção política e administrativa: o químico José Júlio Bettencourt Rodrigues na sociedade portuguesa da segunda metade do século XIX", in José Vicente Serrão, Magda de Avelar Pinheiro e Maria de Fátima Sá e Melo Ferreira (coord.), Desenvolvimento económico e social: Portugal nos últimos dois séculos: Homenagem a Miriam Halpern Pereira, Lisboa: Imprensa de Ciências Sociais, 2009, p. 173-189.

5 Cf. Maria Eduarda Cruzeiro, "Capital simbólico e memória institucional - a propósito da Universidade no século XIX", in Análise Social, vol. XXIV (101-102), $1988\left(2 .^{\circ} 3 .^{\circ}\right)$, p. 593, n2.

${ }^{6}$ Cf. Newton de Macedo, "Instituições de cultura", in Damião Peres (dir.), História de Portugal, Barcelos: Portucalense Editora, 1935, vol. VII, p. 671. 
reforma do ensino que lesava gravemente os interesses da escola de Coimbra, como se vê mais à frente.

É um percurso académico assinalável, mas não menos impressivos são os cargos que desempenhou na política e na administração: foi vereador, no biénio de 1852-1853, e presidente, no de 1858-1859, da Câmara Municipal de Lisboa ${ }^{7}$, deputado às Cortes por Lisboa em mais que uma legislatura e, depois de lhe ter sido conferido o título de 2. ${ }^{\circ}$ Visconde de Vila Maior em 1861, par do reino e presidente interino da Câmara dos Pares ${ }^{8}$.

No parlamento, distinguiu-se sobretudo na área da instrução pública ${ }^{9}$ apresentando vários projetos, entre os quais um projeto de lei que visava uma reforma profunda do Ensino Superior, lido na sessão de 3 de fevereiro de 1854. Nele se elencavam oito ramos de ensino: Teologia, Jurisprudência, Ciências matemáticas, físicas e histórico-naturais, Ciências médicas, Ciências profissionais para os serviços públicos e industriais, Administração pública, Literatura, Belas-Artes, propondo que as Faculdades de Teologia e de Direito continuassem na Universidade de Coimbra; que as ciências matemáticas, físicas e histórico-naturais passassem a ser professadas numa Faculdade de Ciências a criar em Lisboa - extinguindo ipso facto as Faculdades de Filosofia e de Matemática de Coimbra e a Academia Politécnica do Porto, mas ressalvando a manutenção da Escola Politécnica de Lisboa, embora destinada a habilitar somente para os serviços técnicos do Estado

${ }^{7}$ I. B. U. C. (Instituto Botânico da Universidade de Coimbra) - Fundo Visconde de Vila Maior: "Extracto da Acta de Eleição. 16 de Fevereiro de 1852" e "Extracto da Acta de Eleição. 17 de Janeiro de 1858".

${ }^{8}$ I. B. U. C. - Fundo Visconde de Vila Maior: "Ofício do Ministerio do Reino participando que por Decreto de 15 de Julho de 1861 lhe foi conferido o titulo de Visconde de Vila Maior em sua vida", "Carta de mercê de Par do Reino. Paço da Ajuda, 30 de Dezembro de 1862" e "Carta de mercê para presidir á Camara dos Dignos Pares do Reino. Paço da Ajuda, 5 de Janeiro de 1878".

9 A redação de «uma boa lei de instrução publica, que promova principalmente a educação e instrução das classes industriaes e agricultoras» fazia já parte do seu programa político tal como o apresenta em 1846. I. B. U. C. Fundo Visconde de Vila Maior: "Minuta da carta enviada ao Círculo Eleitoral de Bragança em 18 de 7bro de 1846". Mais tarde redigirá, em colaboração com Latino Coelho, o Parecer apresentado á Academia Real das Sciencias com as bases que devem servir de thema á discussão publica sobre a reforma e melhoramento da instrucção nacional, Lisboa, 1857. 
-; que as ciências médicas fossem administradas por uma Faculdade de Medicina e Cirurgia em Lisboa (com uma escola subsidiária no Porto, mas não em Coimbra) e por duas escolas de Farmácia em Lisboa e no Porto $^{10}$. Este projeto, muito polémico, e que ele próprio admitia ser "extremamente revolucionario para a epocha", suscitou pronta reação ${ }^{11}$, não tendo seguimento por falta de apoio do Governo.

Foi sócio, sócio honorário, ou sócio correspondente, de várias instituições científicas, literárias e culturais, nomeadamente da Society of Arts, Manufactures \& Commerce de Londres, da Société d'Encouragement pour 1' Industrie Nationale de Paris, da Reale Accademia Economico Agraria dei Georgofili de Florença, da Sociedad Antropológica Española, da Academia Real das Ciências de Lisboa, da Sociedade de Geografia de Lisboa, da Sociedade Farmacêutica Lusitana, da Associação Industrial Portuense, da Associação Promotora da Industria Fabril, da Sociedade Promotora da Agricultura Michaelense, do Instituto de Coimbra, da Sociedade Terpsichore Conimbricense, da Associação dos Artistas de Coimbra, do Grémio Literário de Lisboa, locais onde procurou divulgar a ciência e a sua aplicação ao mundo social. Nesta última associação, participou na primeira realização de conferências públicas, efetuada no inverno de 1849-1850, proferindo quatro conferências sobre a dependência que a agricultura tem da Química ${ }^{12}$.

${ }^{10}$ Visconde de Villa-Maior, "Sciencias moraes e sociaes. Instrucção Superior", in $O$ Instituto: jornal scientifico e litterario, Coimbra, vol. XLIV, n. ${ }^{\circ}$ 9, Setembro de 1897 , p. 526-528.

${ }^{11}$ A reação da Academia Politécnica do Porto está expressa no texto Breve memoria sobre a Instrucção Superior no Porto e nas provincias do norte; offerecida aos Senhores Deputados da Nação Portugueza, pelos lentes da Academia Polytechnica do Porto, datado de 1 de Maio de 1854.

${ }^{12}$ Como nos informa Vila Maior em texto manuscrito referido mais adiante (na nota 46), no qual menciona também os restantes oradores: Manuel da Silva Bruschy que falou sobre Direito Romano, Andrade Corvo sobre Belas-Artes, Latino Coelho sobre Geologia e António Joaquim de Figueiredo e Silva sobre Botânica. Na obra Os Fastos de Publio Ovidio Nasão com traducção em verso portuguez por Antonio Feliciano de Castilho seguidos de copiosas annotações por quasi todos os escriptores portuguezes contemporaneos, Lisboa: Academia Real das Sciencias, 1862, tomo I, p. CXL, estão também indicadas as palestras de Vila Maior com o título: "A agricultura e a chimica, lições sobre a dependencia em que a agricultura racional está da chimica, professadas no Gremio Litterario em 1849". 
A sua dimensão cívica revelou-se aquando da epidemia de febre amarela que ocorreu em 1857 na capital ${ }^{13}$. Nomeado vogal do Conselho de Saúde Pública do Reino ${ }^{14}$, prestou tão relevantes e valiosos serviços que lhe valeram ser agraciado com a medalha de prata que o Município de Lisboa mandou cunhar para comemorar "os feitos de valor e caridade" praticados naquela crise ${ }^{15}$. Esta calamidade, que dizimou a população ${ }^{16}$, alertou-o para as más condições de salubridade da cidade, persuadindo-o a escrever sobre a urgência da introdução de medidas higiénicas nas habitações ${ }^{17}$, e a fazer do melhoramento da rede de canalização de esgotos uma prioridade na sua vereação ${ }^{18}$.

Logo em janeiro de 1858, o município encarregou o engenheiro da Câmara de elaborar um plano de intervenção urbanística e sanitária, plano que ficou concluído em maio, mas que não foi concretizado por falta de dinheiro, razão essa que levou à demissão de toda a vereação em outubro desse ano, como protesto contra a inexistência de meios financeiros para resolver o problema do saneamento básico

${ }^{13}$ A epidemia surgiu em setembro de 1856 e foi dada como extinta em dezembro de 1857. Cf. Teresa Rodrigues, Nascer e morrer na Lisboa oitocentista: migrações, mortalidade e desenvolvimento, Lisboa: Edições Cosmos, 1995, p. 267-269.

${ }^{14}$ Criado por Decreto de 29 de Setembro de 1857, este Conselho era presidido pelo Ministro dos Negócios do Reino e Secretário de Estado, Marquês de Loulé, e dele faziam parte o Governador Civil de Lisboa, o Presidente da Câmara Municipal de Lisboa, o Enfermeiro-Mor do Hospital Real de São José, os doutores Francisco António Barral, Bernardino António Gomes e Caetano Maria Ferreira da Silva Beirão, lentes da Escola Médico-Cirúrgica de Lisboa, os cidadãos Joaquim Pereira da Costa e Luis Dally e o lente da Escola Politécnica Júlio Máximo de Oliveira Pimentel. I. B. U. C. - Fundo Visconde de Vila Maior: "Cópia autenticada do Decreto de 29 de Setembro de 1857".

${ }^{15}$ I. B. U. C. - Fundo Visconde de Vila Maior: "Ofício da Câmara Municipal de Lisboa, de 20 de Junho de 1859".

${ }^{16}$ «De acordo com os valores populacionais, a TBM causada pela epidemia situa-se em 32,2 por mil, o que significa que em 1857 por cada mil habitantes se registaram mais de trinta e duas mortes devidas à febre». Teresa Rodrigues, Nascer e morrer na Lisboa oitocentista ..., cit., p. 271.

${ }^{17}$ J. M. de Oliveira Pimentel, "Hygiene publica", in Annaes das Sciencias e Lettras, Lisboa: Academia Real das Sciencias, tomo I, Julho 1857, p. 285-288, Setembro 1857, p. 411-417, Outubro 1857, p. 454-468, Novembro 1857, p. 514-524 e Dezembro 1857, p. 581-589.

${ }^{18}$ Cf. Teresa Rodrigues, Nascer e morrer na Lisboa oitocentista ..., cit., p. 274. 
em Lisboa ${ }^{19}$. Embora o seu partido, o partido progressista, tivesse resolvido por unanimidade recandidatar toda a vereação dissolvida, em sinal de apoio à atitude que ela havia tomado, Vila Maior, claramente desgostado com a experiência no governo da edilidade, pediu a retirada do seu nome da lista por entender que se deviam eleger vereadores que: «defendam não só os fóros e franquias municipaes [...], mas tambem que trabalhem incessantemente, fóra de toda a ideia politica, para conquistar, pelos recursos legaes, para a cidade de Lisboa, a força, independencia e os meios indespensaveis para administrar e gerir os interesses municipaes», acrescentando que os seus deveres e as suas ocupações lhe não deixavam livre tempo algum «para trabalhar com a assiduidade necessaria nessa verdadeira campanha municipal ${ }^{20}$.

A versatilidade do seu saber e a diversidade dos seus interesses, além da disponibilidade manifesta para servir a causa pública, levaram-no a aceitar um sem número de comissões. Fez parte da Comissão Central para a Exposição de Paris de 1855, presidida pelo Marquês de Ficalho, e da Comissão de Estudo criada na mesma ocasião especialmente encarregada de se inteirar sobre os progressos e melhoramentos havidos nas diferentes artes e ofícios, foi comissário régio à Exposição de Londres de 1862 e à de Paris de 1867 e comissário geral da Exposição Universal de Paris de 1878, exposições que eram verdadeiras montras da capacidade industrial dos países e onde se jogava muito do prestígio nacional ${ }^{21}$. Sobre esta última exposição, a revista $O$ Occidente fez duas primeiras páginas, publicando numa os retratos do comissário geral, do comissário da secção agrícola, João Inácio Ferreira Lapa, e do comissário da secção industrial, António Augusto de Aguiar e, na outra, uma gravura da fachada do

${ }^{19}$ Ver Álvaro Ferreira da Silva e Ana Cardoso de Matos, "Urbanismo e modernização das cidades: "o embellezamento" como ideal: Lisboa, 1858-1891", in Scripta Nova: Revista Electrónica de Geografía y Ciencias Sociales, Barcelona: Universidad de Barcelona, n. ${ }^{\circ}$ 69, 30, 1 de agosto de 2000.

${ }^{20}$ I. B. U. C. - Fundo Visconde de Vila Maior: "Minuta da carta de 21 de Dezembro de 1858 dirigida a António Rodrigues Sampaio".

${ }^{21}$ Ver, sobre as Exposições Universais oitocentistas, José Amado Mendes, “As Exposições como «Festas da Civilização»: Portugal nas Exposições Internacionais (sécs. XIX-XX)", in Gestão e Desenvolvimento, n. ${ }^{\circ}$ 7, 1998, p. 249-273 e Maria Helena Souto, Portugal nas Exposições Universais 1851-1900, Lisboa: Edições Colibri, 2011. 
Pavilhão Português na Rua das Nações, publicando também uma vista interior da Galeria da Exposição Portuguesa ${ }^{22}$, o que mostra o eco que este tipo de realizações encontrava junto de um público vasto.

Deu ainda o seu contributo em assuntos de perfil variado - sobretudo entre 1851 e 1856, período em que foi parlamentar -, sendo secretário da comissão nomeada em janeiro de 1851 para a Reforma da Moeda ${ }^{23}$, vogal da comissão para a reforma das Pautas Aduaneiras criada em dezembro de 1852, da Comissão Especial de Inquérito ao Banco de Portugal do ano seguinte, da comissão nomeada em setembro de 1847 para proceder à reforma do Colégio Militar, da Comissão Consultiva de Minas criada em agosto de 1850, da comissão para a reforma da Academia Real das Ciências de Lisboa de junho de 1851, do Conservatório Dramático, dos Estatutos da Companhia Lisbonense de Iluminação e Gás de março de 1855, da reorganização do Arsenal do Exército em setembro de 1851 e da Fábrica da Pólvora em março de 1854. Em novembro de 1852, foi nomeado vogal da Secção de Manufacturas do Conselho Geral do Comércio, Agricultura e Manufacturas e, em 17 de junho de 1867, delegado especial pelo Ministério da Fazenda à conferência de Paris que tratava da unificação internacional dos tipos monetários ${ }^{24}$.

Em dezembro de 1856 foi nomeado vogal de uma comissão destinada a fazer a averiguação dos alegados desvios de que era acusado o ex-Secretario Geral da Academia Real das Ciências de Lisboa, o Conselheiro Joaquim José da Costa de Macedo (pendência em que Alexandre Herculano tomara parte ativa), comissão composta ainda pelo Governador Civil de Lisboa, e pelos sócios da referida Academia, Luís Augusto Rebelo da Silva, Albino Francisco de Figueiredo e Almeida, e José da Silva Mendes Leal ${ }^{25}$.

${ }^{22}$ O Occidente: Revista Illustrada de Portugal e do Estrangeiro, 1. . ano, vol. 1, n. ${ }^{\circ} 9,1$ de Maio de 1878 , p. $65,1 .^{\circ}$ ano, vol. 1, n. ${ }^{\circ} 13,1$ de Julho de 1878 , p. 97 e 1. ${ }^{\circ}$ ano, vol. 1, n. ${ }^{\circ} 23,1$ de Dezembro de 1878, p. 180.

${ }^{23}$ Em carta não datada, Fontes Pereira de Melo pede-lhe para redigir o projeto definitivo da Lei da Moeda, assim como duas linhas do relatório para poder apresentar às Cortes. I. B. U. C. - Fundo Visconde de Vila Maior.

${ }^{24}$ No referido Fundo Visconde de Vila Maior encontram-se as nomeações para todas estas comissões.

${ }^{25}$ I. B. U. C. - Fundo Visconde de Vila Maior: "Ofício do Ministerio dos Negocios do Reino de 30 de Dezembro de 1856". 
Integrou também a comissão criada em 24 de dezembro de $1861^{26}$, especialmente encarregada de investigar as causas das doenças que atingiram a família real e levaram à morte do rei $\mathrm{D}$. Pedro $\mathrm{V}$ e dos infantes D. Fernando e D. João, e de fazer um exame ao estado de salubridade dos Paços de Belém e das Necessidades, e suas imediações, para se verificar se havia algumas condições de insalubridade a que se pudessem atribuir aquelas enfermidades. Tinha-se tornado imprescindível o tratamento rigoroso desta questão, por correrem rumores que essas mortes se ficavam a dever à propinação de veneno, rumores que já tinham dado azo a tumultos na capital ${ }^{27}$.

Por fim, foi-lhe cometida em 1883 a missão de elaborar um plano de reestruturação do Ensino Superior ${ }^{28}$, no qual trabalhava quando a morte o surpreendeu ${ }^{29}$. Para bem cumprir esta derradeira missão, e apesar da sua avançada idade e débil saúde, ainda visitou várias escolas em Espanha, França, Itália e Inglaterra. No elogio que o doutor António Cândido Ribeiro da Costa redigiu após o falecimento do visconde,

${ }^{26}$ Comissão de que faziam parte, como presidente, o par do reino e director da Escola Medico-Cirúrgica de Lisboa, José Lourenço da Luz, e como vogais o presidente do Conselho de Saúde Pública do Reino e do Conselho de Saúde Naval, os deputados, doutores Cesário Augusto de Azevedo Pereira, Antonio Egipcio Quaresma Lopes de Vasconcelos e Manuel Pereira Dias, os facultativos José António Marques e Caetano Maria Ferreira da Silva Beirão e os químicos, Visconde de Vila Maior, Sebastião Betâmio de Almeida e Agostinho Vicente Lourenço. I. B. U. C. - Fundo Visconde de Vila Maior: "Cópia autenticada da Portaria do Ministerio dos Negocios do Reino de 24 de Dezembro de 1861".

${ }^{27} \mathrm{Cf}$. Fortunato de Almeida, História de Portugal, tomo VI, 1816-1910, Coimbra: Ed. Autor, 1929, p. 383.

${ }^{28}$ Encargo que ele considerava ter-lhe sido atribuído por razões de ordem estratégica, pois estando a ser alvo de contestação na Universidade e objeto de pedidos de demissão, Fontes Pereira de Melo, chefe do Governo, e Tomás Ribeiro, ministro do Reino, não querendo demiti-lo, mas necessitando de apaziguar o mal-estar existente, encontraram esta forma de o afastar temporariamente. I. B. U. C. - Fundo Visconde de Vila Maior: "Lembranças do serviço da Universidade, 1880-1883".

${ }^{29} \mathrm{O}$ Visconde de Vila Maior faleceu em Coimbra no dia 20 de outubro de 1884, às nove horas da manhã, no edificio da Universidade. Arquivo da Universidade de Coimbra (A. U. C.) - Registos Paroquiais: São Cristóvão. Livro de Óbitos de 1884 , fl. 6v. Deixou um manuscrito do relatório que preparava, o qual foi confiado pela viúva ao Doutor Bernardino Machado, vindo a ser publicado em 1897 no vol. XLIV da revista $O$ Instituto: jornal scientifico e litterario, com o título "Sciencias moraes e sociaes: Instrucção Superior". 
fica patente a admiração que este professor sentia pelo infatigável zelo do seu reitor: «Quem passasse a deshoras perto do paço universitario ${ }^{30}$, ha poucos meses volvidos, distinguiria atravez das janellas do seu gabinete, a modesta luz a que elle redigia os ultimos livros» ${ }^{31}$.

\section{Vida académica e ação militar}

Nascido na vila de Torre de Moncorvo em 5 de Outubro de $1809^{32}$, no seio de uma família abastada ${ }^{33}$, Júlio Máximo de Oliveira Pimentel, futuro Visconde de Vila Maior, viveu a sua juventude e primeiros anos da vida adulta durante um período muito conturbado da história do país, o período difícil da implantação do Liberalismo, época de grande instabilidade social e política, pontuada por vários movimentos militares e marcada por uma guerra civil devastadora. Desde cedo tomou partido pela causa liberal que era, além do mais, tradição de família ${ }^{34}$. Em 1828, quando frequentava na Universidade os cursos de Matemática e de

${ }^{30} \mathrm{O}$ Visconde de Vila Maior vivia, com a mulher, um escudeiro e duas criadas, numa das alas do edifício da Universidade, o antigo Colégio de São Pedro. Ver Guilhermina Mota, Famílias em Coimbra nos séculos XVIII e XIX, Coimbra: Centro de História da Sociedade e da Cultura\ Universidade de Coimbra, 2010. Sep. Revista de História da Sociedade e da Cultura, vol. 10, tomo 2, 2010, p. 363.

${ }^{31}$ Antonio Candido, "[Visconde de Vila Maior]", in Annuario da Universidade de Coimbra: anno lectivo de 1884 a 1885, Coimbra: Imprensa da Universidade, 1884, p. V.

${ }^{32}$ I. B. U. C. - Fundo Visconde de Vila Maior: "Documentos diversos: Cópia autenticada de certidão de baptismo".

${ }^{33}$ Era filho de Luís Cláudio de Oliveira Pimentel, sargento-mor de Moncorvo, que veio a ser o $1 .^{\circ}$ visconde de Vila Maior - título concedido por Decreto de 1 de junho de 1858 - e neto de João Carlos de Oliveira Pimentel, cavaleiro da Ordem de Cristo, capitão-mor de Moncorvo, administrador-geral dos tabacos e sabões nessa vila e donatário das barcas do Douro. I. B. U. C. - Fundo Visconde de Vila Maior: "Documentos diversos".

${ }^{34} \mathrm{O}$ seu pai e o seu tio, o General António José Claudino de Oliveira Pimentel, foram presos pelos absolutistas em Junho de 1828, e condenados depois, o primeiro a três anos de prisão em Peniche e a $200 \$ 000$ réis para as despesas da alçada e o segundo a degredo para Angola (presídio das Pedras Negras) e a $400 \$ 000$ para as ditas despesas, vindo este último a falecer antes do embarque. Ver Francisco Manuel Alves, Reitor de Baçal, Memorias arqueologico-historicas ..., cit., p. 400. 
Filosofia ${ }^{35}$, viu-se obrigado a abandonar Coimbra para não ser expulso e preso, o que fez a conselho do professor Tomé Rodrigues Sobral ${ }^{36}$, seu conterrâneo e seu amigo. Estalada a guerra, apresentou-se no Porto ao exército liberal, ficando colocado no Batalhão de Voluntários Académicos. Distinguiu-se em alguns recontros e sobretudo na defesa da Serra do Pilar $^{37}$ - é um dos célebres polacos da serra ${ }^{38}$-, onde foi ferido numa perna, ferimento que o marcou para sempre.

Em reconhecimento do valor militar demonstrado enquanto voluntário académico, foi integrado no exército na arma de Infantaria com o posto de alferes ${ }^{39}$, o que lhe abriu a carreira militar, como aconteceu com outros nas mesmas circunstâncias. Mas, ou por se sentir incapaz para o serviço militar ativo por causa da lesão sofrida, ou por índole e temperamento, não foi à carreira das armas que se veio a devotar.

Restabelecida a paz em 1834, regressou a Coimbra para retomar os estudos interrompidos, vindo a adquirir o grau de bacharel em Matemática três anos depois ${ }^{40}$. Tinha então em mente ir para Paris

${ }^{35}$ A. U. C. - Livro de matrículas da Universidade de Coimbra ."Primeiro Anno Mathematico" e "Primeiro Anno Filosofico", n. . 54, 1826-1827, fl. 219v e 256; Livro de matrículas da Universidade de Coimbra. "Segundo Anno Mathematico" e "Segundo Anno Filosofico", n. . 55, 1827-1828, fl. 216 e 254v. Este último assento tem à margem: "Riscado por Aviso R. de 28 de Março de 1829" e "Foi admittido a fechar a Matricula por Despacho de 11 de Dezembro de 1834".

${ }^{36}$ Júlio Augusto Henriques, "Visconde de Villa Maior", cit., p. IX.

${ }^{37} \mathrm{O}$ que lhe valeu a condecoração com a Ordem da Torre e Espada. I. B. U. C. - Fundo Visconde de Vila Maior: "Carta de mercê a Julio Maximo de Oliveira Pimentel, voluntario do Corpo Académico, de o nomear Cavaleiro da Ordem da Torre e Espada do Valor Lealdade e Merito por decreto de 23 de 9 bro ultimo em atenção aos feitos singulares praticados por elle na defeza do posto fortificado da Serra do Pilar, no dia 14 de Outubro do mesmo. Porto 28 Fevereiro 1833. Duque de Bragança, Regente em nome da Rainha".

${ }^{38}$ Epíteto que foi atribuído por D. Pedro IV aos defensores da Serra do Pilar, ao assistir à heróica resistência que opuseram aos assaltos do exército miguelista, lembrando a insurreição nacionalista polaca de 1830-1831.

${ }^{39}$ I. B. U. C. - Fundo Visconde de Vila Maior: "Carta patente de nomeação de Julio Maximo Pimentel, Voluntario Académico, Alferes do Batalhão de Caçadores numero tres. Lisboa, 31 de Agosto de 1838, a Rainha".

${ }^{40}$ A. U. C. - Livro de Matrículas da Universidade de Coimbra. "Segundo Anno Mathematico" e "Segundo Anno Filosofico", n. o 58, 1834-1835, p. 96 e 109v; "Terceiro Anno Mathematico" e "Terceiro Anno Filosofico", n. . 59, 1835-1836, fl. 226v e 153v; "Quarto Anno Mathematico", n. ${ }^{\circ}$ 60, 1836-1837, fl. 192v. 
cursar Engenharia Civil na Escola de Pontes e Calçadas, mas o seu destino seguiu outro rumo.

Em 1836, Passos Manuel efetuou uma larga reforma do ensino que abrangeu o ensino primário, secundário e superior. Neste último, foram criadas novas escolas, entre as quais a Escola Politécnica de Lisboa, estatuída por decreto de 11 de janeiro de 1837. Era sua finalidade essencial preparar os que se destinavam aos serviços técnicos e militares do Estado e acessoriamente contribuir para propagar a instrução científica superior. Essa preparação envolvia as ciências matemáticas, físicas e naturais com um quadro de dez disciplinas fundamentais ${ }^{41}$. Júlio Pimentel foi convidado para reger a 6. disciplina, a de Química, o que aceitou após alguma hesitação. Nomeado professor, em dezembro de 1837, por necessidade urgente de serviço ${ }^{42}$, só foi provido na propriedade da cadeira depois de vencer, no final do ano letivo, o concurso público aberto para o provimento da mesma, que constou de exame oral, escrito e experimental. Pimentel empenhou-se então no desenvolvimento do ensino da Química, na organização do primeiro laboratório de Química da Escola Politécnica (provavelmente adaptado da cozinha do extinto Colégio dos Nobres, em cujo edifício a escola estava instalada) ${ }^{43}$, e na publicação de um primeiro compêndio para os alunos ${ }^{44}$.

Fez exame das disciplinas do $4 .^{\circ}$ Ano de Matemática e adquiriu o seu grau de bacharel em 16 de Junho de 1837. Livro de Exames do $4 .^{\circ}$ Anno de Mathematica de 1836 para 1837, fl. 214.

${ }^{41}$ Cf. Newton de Macedo, “Instituições de cultura”, cit., p. 661-662 e 670.

${ }^{42}$ I. B. U. C. - Fundo Visconde de Vila Maior: "Cópia autenticada do Decreto de 9 de Dezembro de 1837, enviada pela Secretaria de Estado dos Negocios da Guerra".

${ }^{43}$ Ver Isabel Cruz, "Preparadores de Química da Escola Politécnica (1837-1856)", cit.

${ }^{44}$ Júlio Máximo de Oliveira Pimentel, Curso de chymica elementar professado na Escola Polytechnica, Lisboa: Impressão de Galhardo Irmãos, 1839. 


\section{Estada em França como bolseiro e viagens de estudo ${ }^{45}$}

Oliveira Pimentel, desde o início da atividade docente, manifestara o desejo e a conveniência de estudar em Paris para aprofundar e atualizar os seus conhecimentos. A possibilidade de concretizar esse desejo surgiu em 1844 quando a Escola Politécnica contratou um professor substituto para a cadeira de Química - Joaquim Henriques Fradesso da Silveira -, e ele foi autorizado a sair. Foi-lhe concedida uma bolsa de 600 francos (à volta de cem mil réis) mensais, incluindo esta quantia o ordenado de professor e o soldo de militar, sendo portanto, em rigor, a parte que cabia à bolsa apenas de $27 \$ 067$ réis $^{46}$. Era pouco para viver na grande cidade com a família, mas abraçou com entusiasmo o ensejo de trabalhar num meio científico dos mais adiantados da Europa. E embora o objetivo que o motivava fosse muito preciso, que era o da sua preparação científica e académica, usufruir da riqueza cultural e da modernidade desse mundo a que acedia também estaria nos seus horizontes, pois viajar na civilização era tido ainda como a forma mais acabada de aprender ${ }^{47}$.

Partiu para França em setembro de 1844 acompanhado pela mulher, Sofia de Roure Auffdiener, e pela filha Júlia, criança de quatro anos, deixando em Portugal o filho Emílio então bebé de meses. Fez a viagem de navio até Southampton, passando depois a Le Havre donde seguiu de diligência até Ruão e depois por caminho de ferro até Paris, transporte, este último, à época, ainda uma novidade. A primeira impressão que tem da cidade não corresponde à imagem grandiosa que dela fizera. Esse desapontamento talvez se compreenda porque, antes da grande transformação urbanística dirigida por Haussmann, a cidade apresentava, como se diz na revista $O$ Panorama, «muitas ruas estreitas,

\footnotetext{
${ }^{45}$ Sigo de agora em diante um manuscrito de memórias, que abrange os anos de 1844 a 1855, redigido pelo Visconde de Vila Maior, e que se encontra, sem título, no arquivo histórico do Instituto Botânico da Universidade de Coimbra.

${ }^{46}$ Cf. Julio A. Henriques, "Visconde de Villa Maior", cit., p. XI.

${ }^{47}$ Assim pensava, por exemplo, o rei D. Pedro V, como nos diz Ruben Andresen Leitão, Diário de viagem a França del-Rei Dom Pedro V, Paris: Centro Cultural Português, Fundação Calouste Gulbenkian, 1970, p. 24.
} 
sujas e escuras», com muitas casas «velhas e denegridas pelo tempo e a humidade do clima» ${ }^{48}$.

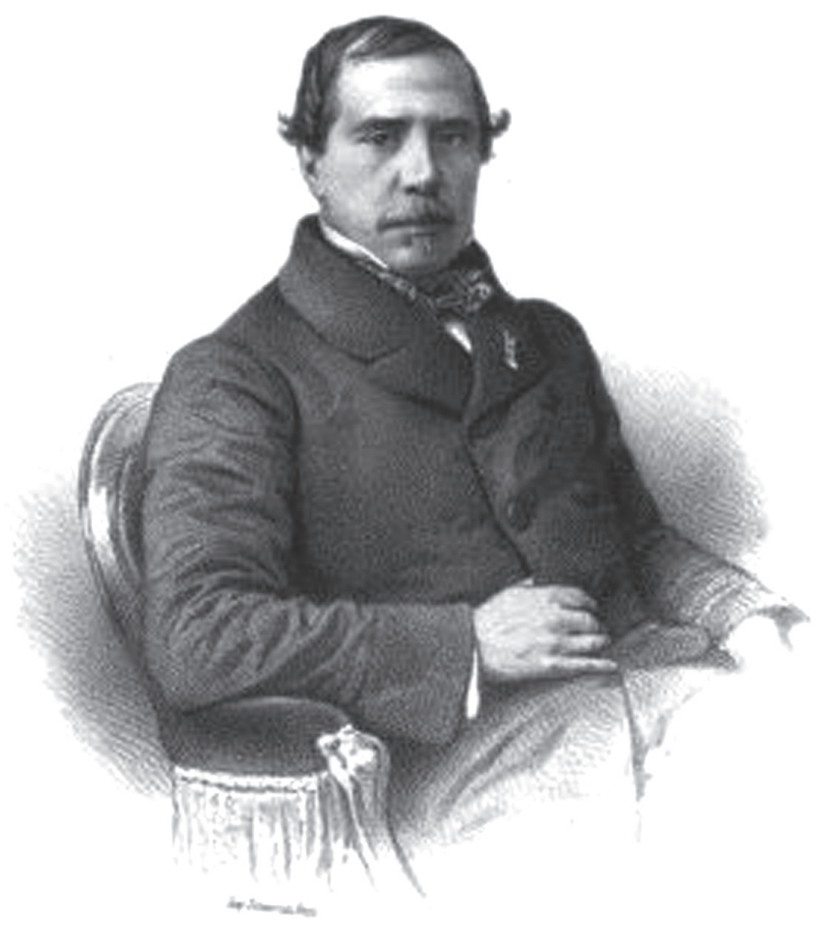

Júlio Máximo de Oliveira Pimentel (ca. 1850)9

Ao chegar, o ministro de Portugal, o Visconde da Carreira, Luís António de Abreu e Lima, a quem se apresentou, recebeu-o com alguma indiferença. Latino Coelho considerará mais tarde que a falta de atenção e de apoio do diplomata se terá ficado a dever em parte ao facto de este duvidar «que existisse uma sciencia chamada chimica e de que o seu ensino fosse proveitoso a Portugal» ${ }^{50}$.

${ }^{48} \mathrm{O}$ Panorama, Lisboa: Imprensa da Sociedade Propagadora dos Conhecimentos Uteis, n. ${ }^{\circ}$ 76, 10 Junho 1843, p. 178.

${ }^{49}$ Biblioteca Nacional Digital.

${ }^{50}$ J. M. Latino Coelho, “Julio Maximo de Oliveira Pimentel”, cit., p. 565. 
Em contrapartida, foi calorosamente recebido por amigos que então se encontravam em Paris, alguns, exilados na sequência da revolta de fevereiro contra o ministério de Costa Cabral, como José Estêvão, Mendes Leite, o Conde do Bonfim ${ }^{51}$ e, acima de todos, por Sebastião Carlos Navarro de Andrade, seu companheiro desde o tempo do Batalhão Académico, que o guiou nos «primeiros passos no labyrinto d' aquella Babilonia».

Depois de acomodado com a família num $2 .^{\circ}$ andar de uma casa ao cais des Grands Augustins perto da ponte de S. Michel - pela qual pagava 700 francos por trimestre, renda bastante elevada para as suas posses, mas cuja opção obedeceu ao desejo demonstrado pela mulher de viver junto do rio Sena -, tratou de organizar a sua vida de estudante.

O plano de estudos que traçara englobava, por um lado, a frequência dos cursos de Química mais importantes, sobretudo o de Jean-Baptiste Dumas, então professor titular da Faculdade de Ciências de Paris e, por outro, e principalmente, entrar para um laboratório onde se pudesse instruir nos trabalhos de investigação.

Estando, por estes anos, a prática laboratorial em definitivo estabelecida na ciência química, começaram a aparecer laboratórios à imagem do que Justus Liebig ${ }^{52}$ tinha em Giessen: unidades de ensino e de investigação, constituídas por um professor e investigador principal, investigadores, alunos de investigação, preparadores e auxiliares de laboratório. Os custos elevados da constituição e da manutenção dos laboratórios eram em parte colmatados com a admissão de estagiários que afluíam vindos de diversos pontos da Europa e não só ${ }^{53}$, muitos deles já abonados com formaturas universitárias, e que procuravam

${ }^{51}$ Os quais se encontravam exilados em Paris depois de terem tomado parte em fevereiro de 1844 na tentativa revolucionária liderada por António César de Vasconcelos Correia, mais tarde Conde de Torres Novas, para derrubar o governo cabralista. Ali permaneceram até 1846, ano em que a Revolução da Maria da Fonte provocou a queda dos irmãos Cabral e em que regressaram a Portugal.

${ }^{52}$ É atribuído um papel determinante a este químico alemão na mudança radical havida no século XIX nos métodos de ensino da Química, ao criar uma ligação estreita entre ensino e investigação.

${ }^{53}$ Ver, sobre os laboratórios de Química nesta época, Raquel Gonçalves, "Instituições: os laboratórios de Química", in Ana Luísa Janeira, Maria Estela Guedes e Raquel Gonçalves (coord), Divórcio entre cabeça e mãos?: laboratórios de Química em Portugal (1772-1955), Lisboa: Livraria Escolar Editora, 1998, p. $12-18$. 
aprofundar o seu saber. Os cursos de Química ministrados não previam o tempo suficiente para consolidar os conhecimentos da prática laboratorial, e assim os estudantes não ficavam qualificados para prepararem e regerem um curso ${ }^{54}$.

No caso particular de Júlio Pimentel, a necessidade de consolidar os conhecimentos era ainda mais patente pois era matemático e, como tal, a sua formação académica de base em Química fora reduzida ${ }^{55}$. Não admira assim que os seus primeiros passos fossem encaminhados para a procura de um laboratório onde pudesse praticar. Desde logo resolveu não invocar qualquer patrocínio oficial, e assumir-se como simples estudante. Na "peregrinação" pelos laboratórios contou com a boa vontade e com o auxílio de Sebastião Betâmio de Almeida (que veio a ser mais tarde professor da Escola Industrial do Porto), químico há anos residente na capital francesa e seu conhecido, que fora preparador no laboratório da Escola Politécnica de Paris e por isso conhecia bem o meio científico parisiense da Química.

A primeira escolha recaiu no laboratório privado que Theóphile Pelouze, professor no Colégio de França e na Escola Politécnica de Paris, havia estabelecido na Rue Dauphine. Era um laboratório de ensino e de investigação muito reputado, à imagem do da Universidade de Giessen onde Pelouze trabalhara com Justus Liebig. A visita que Júlio Pimentel fez ao laboratório, porém, desiludiu-o. Por um lado, Pelouze estava quase sempre ausente, entregando a direção dos trabalhos a Edmond Frémy, que era nesta altura preparador e assistente de Pelouze na Escola Politécnica, e a Charles Barreswill que aqui começou como estudante. Por outro lado, o laboratório tinha uma afluência de grande número de alunos, o que considerou constituir um elemento de distração. Acrescia que a mensalidade pedida era de 100 francos, quantia demasiado alta para a sua bolsa.

${ }^{54}$ Ver Isabel Cruz e Sandra Lopes, "Chemistry «laboratory hands» in Portugal in the nineteenth century: aspects of an evolution", in Neighbours and territories: the evolving identity of Chemistry: the $6^{\text {th }}$ International Conference on the History of Chemistry, Louvain-la-Neuve: Mémosciences, 2008, p. 550.

${ }^{55} \mathrm{O}$ currículo do curso de Matemática integrava então apenas uma cadeira de Química. 
Tentou depois o laboratório do Colégio de França onde era preparador o filho do Barão de Thenard ${ }^{56}$ que, embora estivesse interessado em ter um auxiliar não remunerado que o substituísse no laboratório, pôs como condição que "se alistasse" no laboratório de Pelouze a quem não queria prejudicar nos seus interesses, ou seja, que aí pagasse os 100 francos mensais, proposta que não aceitou.

Emseguida,foiaolaboratóriodoJardimdasPlantas,oprincipal Jardim Botânico de França, onde Louis Gay-Lussac era professor de Química. Embora o nome deste proeminente físico e químico, que havia sido professor de Física na Sorbonne e abandonara o lugar em 1832 para se ocupar da cátedra de Química neste Jardim, só por si fosse uma garantia de qualidade, a verdade é que lhe pareceu que neste laboratório se trabalhava pouco. Ademais, ficava muito distante de casa e assim também lhe não conveio, embora o preço fosse mais módico: 50 francos por mês.

Passou depois ao Conservatório Nacional das Artes e Ofícios, escola de ensino público e gratuito ligado às artes industriais, com o fim de ver o laboratório do químico Anselme Payen que, tendo começado por se dedicar à produção química industrial, a partir de 1835 se tornou professor, primeiro na Escola Central de Paris e depois no referido Conservatório, e se entregou em exclusivo à investigação. Oliveira Pimentel também não optou por este laboratório por o ensino ser aí particularmente destinado à Química Industrial e ele precisar de uma formação mais geral com vista ao curso que tinha de ministrar em Lisboa.

Porém, no Conservatório, passou por uma porta que tinha a inscrição "Laboratoire de Mr. Peligot". Eugène Peligot foi um químico insigne que desenvolveu uma investigação diversificada, desde o crómio, o urânio ou o ferro, até aos açúcares, aos fertilizantes, à água potável, à estrutura do vidro e ao bicho da seda, notabilizando-se por ter sido o primeiro a isolar o urânio, em 1841, e por haver em 1844 realizado a primeira experiência que resultou na formação de cristais de carboxilato de cromo. Este laboratório tinha no seu quadro um preparador e costumava ter um ou dois auxiliares que o professor só aceitava já com prática de Química. O preparador do laboratório, Pierre Favre (físico e médico, mais tarde professor na Faculdade de

${ }^{56}$ Louis Jacques Thenard (1777-1857), químico francês de origem humilde que foi feito barão por Carlos X em 1825. Foi professor na Faculdade de Ciências de Paris e no Colégio de França. 
Medicina de Marselha) ficou agradado com a possibilidade de ter um auxiliar, uma vez que se encontrava sozinho, pois o anterior, Maumené, tinha saído para estabelecer um laboratório seu. Peligot recebeu Pimentel com afabilidade e, depois de se inteirar «prefunctoriamente» do seu saber em Química, admitiu-o a praticar no seu laboratório gratuitamente, ou melhor, pagando somente com o serviço prestado. Este acordo realizava o anseio de Júlio Pimentel de poder praticar num laboratório acreditado sem gastar dinheiro e, para além disso, estimulava-o a ser assíduo.

Começou imediatamente a trabalhar no laboratório e simultaneamente a seguir alguns cursos. No início, em Outubro, começou por seguir o único que estava aberto, o de Michel Eugène Chevreul sobre Química aplicada à tinturaria que ele professava na Manufatura Nacional des Gobelins, fábrica que produzia tapeçarias de alta qualidade que se distinguiam pela excelência dos materiais e dos tintos, e onde era diretor da secção de tinturaria. Assistia às aulas duas vezes por semana, às 9 horas da manhã. Acompanhou-o durante algum tempo, embora incidisse numa temática demasiado circunscrita para aproveitar a quem tinha de reger um curso de Química Geral.

Depois, também duas vezes por semana, passou a assistir às aulas de Química que Jean-Baptiste Dumas, que se destacou sobretudo em Química Orgânica, proferia na Sorbonne, cujas notas redigia à noite em casa. Penso que terá sido este o mestre que mais influência exerceu sobre o nosso químico, a avaliar pelas referências amiudadas que irá fazer às suas ideias e ensinamentos nos seus escritos, se bem que estes reflitam também o muito que aprendeu com Peligot.

Presenciou igualmente as aulas de Mathieu Orfila, professor de Química na Faculdade de Medicina de Paris e, no Jardim das Plantas, ainda foi ouvir algumas vezes as lições de Gay-Lussac, que nesse ano de 1845 regeu pela última vez, ficando «encantado com a clareza e a simplecidade engenhosa da sua exposição», lamentando que as suas muitas obrigações e a distância a que o Jardim ficava de casa lhe não permitissem comparecer de modo mais continuado.

Durante o dia consagrava a maior parte do tempo aos afazeres do laboratório. Peligot encarregava-o da preparação das substâncias que eram necessárias para a determinação de alguns equivalentes metálicos, de fazer também as análises dessas substâncias, e de o coadjuvar em muitos dos seus trabalhos, como a análise dos vidros e cristais da 
Boémia e nos estudos que empreendeu mais tarde para verificar a teoria da elaboração da seda pelo sirgo. Além disso, o preparador do laboratório, Favre, ao tempo já mais interessado nos estudos das calorias que desenvolvia com Johann Silbermann (o qual foi assistente do laboratório e depois conservador das coleções no Conservatório), para ter mais tempo livre para eles, abusava da solicitude do auxiliar e entregava-lhe a preparação das demonstrações para o curso de Química que Peligot fazia duas vezes por semana no Conservatório das Artes e Ofícios. Júlio Pimentel sujeitava-se por considerar essas tarefas de grande utilidade para futura aplicação no seu próprio curso em Portugal.

Como do seu plano de estudos também constava a deslocação à Universidade de Giessen para frequentar Química Orgânica com Liebig, resolveu preparar-se com a aprendizagem da língua alemã, para o que se matriculou na Escola de Robertson na rua de Richelieu. Ainda assistiu às lições durante dois meses, mas acabou por desistir, porque estas eram em horário noturno, o que o impedia de fazer companhia à mulher nas longas noites de inverno.

O estudo, o trabalho e as finanças pouco abundantes, não deixavam ao casal muito espaço para se lançar no "grande mundo". Serões com amigos, umas idas esporádicas ao teatro ou à ópera, onde viram atuar os mais famosos atores e cantores da época, como a Grisi, a Persiani, Mlle Rachel, Victor Petipa, Lablache ou Ronconi, no Teatro Italiano, na Comédie Française ou na Ópera Cómica, constituíam os seus passatempos. O inverno de 1845 foi muito rigoroso, em que pouco se viu o sol e o frio era tal que era imperioso ter o fogão constantemente aceso. Só quando chegou a primavera puderam dar alguns passeios na cidade e nos seus arrabaldes. Visitaram os museus, o Jardim das Plantas, o Bosque de Bolonha, a fábrica dos Gobelins, as igrejas mais notáveis, o Panteão, os Inválidos, o Cemitério do Père Lachaise, e tudo o mais que os guias de Paris indicavam aos viajantes, e foram a Versalhes, na companhia de José Estêvão.

As saudades da pátria e da família levaram a mulher a querer regressar com a filha a Lisboa, não sem antes fazerem todos uma digressão até Laval a visitar uma tia que os havia convidado. Pimentel foi daí até Nantes e, juntamente com o cônsul português, examinou alguns estabelecimentos industriais, como refinarias de açúcar, uma padaria mecânica, uma fábrica de chumbo, a de produtos químicos de Cartier e a grande Usine des Indres, onde se construíam os vapores transatlânticos. 
Ficando depois sozinho em Paris, continuou a frequentar o laboratório de Peligot e os cursos no bairro latino. Um encontro casual vai entretanto determinar uma alteração nos planos de aprendizagem traçados. Quis o acaso que se cruzasse na Ópera Cómica com o empresário José Maria Eugénio de Almeida ${ }^{57}$ que chegara a Paris em Junho de 1845. Tinha-se constituído em Lisboa a Companhia das Obras Públicas $^{58}$, de que ele era diretor, sendo também o principal Caixa ${ }^{59}$ da Companhia do Tabaco, Sabão e Pólvora, companhia que teve o monopólio de produção e comercialização dos referidos produtos em Portugal entre 1846 e 1858. Vinha com o objetivo de adquirir maquinaria, contratar engenheiros e estabelecer relações no mundo industrial, a fim de lançar a grande empresa das obras públicas e de melhorar a exploração dos monopólios.

Da conversa então havida resultou o convite que Eugénio de Almeida lhe formulou para se incumbir da direção da fábrica de Saboaria do Paço do Bispo e também o pedido para lhe indicar alguma indústria onde ele e os seus amigos do contrato - o Contrato do Tabaco estava então num grupo em que se destacavam, para além de José Maria Eugénio de Almeida, José Isidoro Guedes, futuro Conde de Valmor, e Joaquim Ferreira dos Santos, futuro Conde de Ferreira ${ }^{60}$ - pudessem empregar os grandes capitais de que podiam dispor.

Depois de ver algumas fábricas, Eugénio de Almeida decidiu-se pela instalação de uma refinaria de açúcar e encarregou Pimentel de fazer os projetos e encomendas de máquinas, prometendo-lhe interesse nessa firma. Ao mesmo tempo, e como não era incompatível com a

${ }^{57}$ José Maria Eugénio de Almeida (1811-1872), importante empresário do século XIX, que chegou a par do reino e conselheiro de Estado, notabilizando-se no mundo dos negócios como contratador, financeiro, especulador, industrial e grande proprietário. Para informação mais aprofundada, ver Helder Adegar Fonseca e Jaime Reis, "José Maria Eugénio de Almeida, um capitalista da Regeneração", in Análise Social, vol. XXIII (99), 1987 (5.), p. 865-904.

${ }^{58}$ A Companhia das Obras Públicas de Portugal foi uma companhia formada em 19 de dezembro de 1844 por um grupo de capitalistas com o objetivo de efetuar todas as grandes obras necessárias ao melhoramento das comunicações do país, objetivo que não cumpriu encerrando com saldo negativo em 1856.

${ }^{59}$ Designação por que eram conhecidos os arrematantes do Contrato do Tabaco, contrato pelo qual o Estado arrendava a particulares a produção e comercialização do tabaco.

${ }^{60}$ Ver Maria Filomena Mónica, "Negócios e política: os tabacos (1800-1890)”, in Análise Social, vol. XXVII (116-117), 1992 (2. $\left.{ }^{\circ}-3 .^{\circ}\right)$, p. 464. 
regência da cadeira de Química na Escola Politécnica, este assentiu na direção da fábrica do sabão, o que melhorava a sua situação financeira.

Para ficar apto a dirigir a fábrica com maior competência, resolveu ir até Marselha para aí estudar os métodos de fabrico utilizados nas indústrias do sabão. A cidade francesa era, desde a Idade Média, um centro de produção de sabões de superior qualidade, e as fábricas tinham mantido os altos padrões tradicionais da fabricação artesanal.

Antes, porém, ainda realizou uma viagem pela Bélgica, pelo Reno e pela Suíça, passando por Giessen e por outras cidades alemãs para ver as universidades e especialmente os laboratórios de Química. Examinou também unidades industriais de ponta para se informar sobre as mais recentes conquistas da tecnologia para posterior aplicação na indústria em Portugal.

No início do mês de julho saiu assim de Paris e dirigiu-se à Bélgica, primeiro a Bruxelas, onde viu uma fábrica de sabão, a de refinação da Sociedade Nacional, fábricas de serração de madeira, padarias mecânicas, as oficinas de construção da Companhia de Derosne \& Cail, firma que produzia uma grande variedade de máquinas industriais, e depois a Malines para observar o centro da rede ferroviária da Bélgica localizado nessa cidade.

Bem acolhido pelos reitores e diretores, esteve também em múltiplas universidades: na Universidade Livre de Bruxelas, à época ainda muito no início, na de Lovaina, onde considerou o Gabinete de Física, as galerias de História Natural e a Biblioteca bem dotados e bem organizados, na de Liège e na de Gand.

Foi depois a Seraing, juntamente com Eugénio de Almeida e o cônsul português em Bruxelas, analisar aquele que era nesse tempo um dos estabelecimentos industriais de mais nomeada no continente, a Metalurgia John Cockerill, um dos maiores produtores de ferro e aço, assim como de maquinaria. Aí foram recebidos por um dos diretores que lhes deixou ver todas as oficinas, desde os altos fornos, até às serralharias das mais delicadas máquinas, as minas de carvão de pedra, os numerosos fornos de coke e tudo o mais que dava uma ideia da grandeza industrial do estabelecimento. Ficou muito impressionado com o prodigioso trabalho metalúrgico e mais ainda com «o poder da sciencea e do engenho humano».

Como homem de cultura aproveitou a sua estada na Bélgica para apreciar as belas catedrais, os edifícios, os jardins, os museus e as obras 
de arte. Também as paisagens e as povoações que avistou lhe causaram grande admiração, assim como «a infinidade de fabricas, cujas altas chamines vomitam constantemente columnas de espesso fumo», admiração pelo poder da indústria que gerava o conforto e o bem-estar que é bem do seu tempo, ainda não abalado por problemas ecológicos. Foi ainda a Spa, cidade afamada pelas suas termas, examinando os banhos e também a Reduta, casa que é considerada o primeiro casino moderno.

Seguiu depois para a Prússia Renana, passando por Colónia, Bona, Coblença, Mogúncia, Francoforte, com destino a Giessen, onde queria ver o laboratório de Liebig a quem vinha recomendado por Pelouze. Esta era uma pequena cidade e toda a sua importância provinha da escola de Química Orgânica. Liebig mostrou-lhe o laboratório onde havia mais de 60 alunos. Explicou-lhe o seu método de ensino e todos os melhoramentos que introduzira e pô-lo ao corrente dos trabalhos em curso no laboratório. Ao ver como ali se procedia, arrependeu-se um tanto de ter abandonado o seu primeiro plano de estudos que previa a estada de alguns meses em Giessen. Da Alemanha passou à Suíça, não deixando em todos estes locais, em paralelo com a romagem científica, de contemplar o que de mais precioso havia, de usufruir de concertos, peças de teatro e de ópera, e de dar os seus passeios.

Nestas jornadas, uma boa parte dos trajetos foi já percorrida em caminho de ferro, mas utilizou também o transporte por estrada, mais lento, nas diligências com as suas estações de muda, e em omnibus em percursos mais curtos, assim como o transporte por via fluvial, subindo ou descendo os grandes cursos de água, como os rios Meuse, Reno e Ródano, ou vogando pelos lagos de Bienne e de Genebra na Suíça.

Partiu finalmente para Marselha. O que primeiro despertou a sua curiosidade foi a obra em curso do Aqueduto de Roquefavour (construído entre 1841 e 1847), aqueduto que se destinava a conduzir parte da água da ribeira de Durance para Marselha. É considerada uma grande obra de engenharia, com três ordens de arcos sobrepostos, com mais de 80 metros de altura, e cujo canal obrigou à abertura de túneis em rocha viva. Apreciou as condições de trabalho, pois tudo se fazia com o auxílio de máquinas, reduzindo ao mínimo o emprego da força dos homens.

Passava as manhãs nas visitas de estudo às fábricas de sabão, cujo impacto na cidade se pode avaliar pela descrição que faz da vista que 
se gozava da Montanha Bonaparte, com a cidade e o antigo porto em baixo «como abrigados por um vêo de fumo e espessos vapores que na atmosphera derramam as numerosas fabricas de sabão».

Fez ainda algumas digressões no Sul de França, indo a Saint Chamas (onde visitou a Poudrerie Royale, a grande fábrica de pólvora estatal, criada por Colbert em 1690), a Arles, Nîmes e Gard (cidades onde admirou as construções do tempo da antiga Roma), e a Montpellier, onde visitou a Escola de Medicina.

No fim de setembro, seguiu para Londres. Esta viagem não era ditada por mera recreação turística, pois tinha como programa encomendar aparelhos para a fábrica de sabão do Contrato, estudar, se fosse possível, os métodos de fabrico ingleses, e ao mesmo tempo visitar os estabelecimentos de Ensino Superior.

Com a abonação do ministro então acreditado em Londres, o Barão de Torre de Moncorvo, que era amigo de família, foi visitar o King's College e o University College, o Museu de Geologia, o Museu Nacional, o Real Colégio de Cirurgiões. Fez ainda algumas excursões pelos arredores da cidade, e entre elas uma a Greenwich onde, também com recomendação especial, viu todo o Observatório (Royal Greenwich Observatory) e o Hospital dos Inválidos da Marinha.

Em Londres, foi algumas vezes ao Queen's Theatre e ao Covent Garden, teatros onde voltou a ver atuar alguns dos artistas que já conhecia de Paris e onde ouviu a célebre soprano Jany Lind, cujo canto o maravilhou.

No fim de outubro voltou para Paris e retomou a sua atividade no laboratório de Peligot, onde já não trabalhava Favre que tinha instalado um laboratório seu. Conheceu então Jules Buis com quem vai desenvolver uma pesquisa sobre matérias gordas vegetais, como as provenientes do brindão e da mafurra - plantas que existiam respetivamente no domínio português da Índia e em Moçambique -, cujos resultados serão por eles apresentados à Academia das Ciências de Paris que os publica ${ }^{61}$. Simultaneamente, assistia aos cursos de

${ }^{61}$ "Composition de la stéarine végétale extracté des grames du brindonnier (Brindonia indica)", in Comptes Rendus de l'Académie des Sciences, Paris, tomo 44, 1857 e "Nouvelle production de l' acide palmitique par le suif de mafurra", in Comptes Rendus de l' Académie des Sciences, Paris, tomo 41, 1855. 
Ciências e tratava da organização dos planos para a fábrica de refinação de açúcar de que o encarregara José Maria Eugénio.

\section{Regresso a Portugal: atividade científica e participação na área económica}

Em fevereiro de 1846 encerrou esta fase da sua preparação e regressou a Portugal. Era hora de corresponder ao investimento feito pelo governo português ao atribuir-lhe a bolsa, e de voltar à sua Escola Politécnica a iniciar um ensino atualizado da Química. Também era tempo de dar conta das suas diligências aos contratadores do tabaco no que respeitava à fábrica de sabão e ao estabelecimento da refinaria de açúcar.

Ao chegar, nada correu como previsto. Em abril irrompeu o movimento da Maria da Fonte que se tornou tão grave que as aulas das escolas se fecharam e Oliveira Pimentel não teve ocasião de abrir o curso. Entregou-se assim à preparação das lições para quando tivesse de começar a regê-lo, o que só em março de 1848 viria a suceder. Por outro lado, verificou-se também grande alteração no acordo que firmara em Paris com Eugénio de Almeida: já não ficava encarregado da direção e da reforma da fábrica do sabão, o que lhe renderia 1:200\$000 réis, mas apenas da inspeção e de aconselhamento, com metade do salário. Acedeu, porque assim também tinha menos trabalho e menos responsabilidade.

Maior dificuldade surgiu na empresa da refinaria do açúcar. Em Paris ficara tudo ajustado com a companhia Derosne \& Cail para que em maio seguissem para Lisboa os aparelhos para a fábrica, o engenheiro para a estabelecer e o mestre refinador, devendo fazer-se o último pagamento aos construtores à saída dos aparelhos. Não tendo disponibilidades financeiras para honrar o compromisso, José Maria Eugénio pediu a Júlio Pimentel que escrevesse para Paris solicitando a suspensão da remessa, justificando-a com os embaraços trazidos pela insurreição popular. Conseguiu-se um mês de espera, mas como o estado de coisas se não alterasse, Pimentel propôs que passassem o negócio ao empresário J. Ferreira Pinto, que nele estava interessado, o que veio a acontecer.

Concentrando-se então na empresa de sabão, aconselhou os contratadores, uma vez que estes tinham o monopólio por 12 anos, a estabele- 
cerem uma fábrica de soda, produto que era essencial à fabricação do sabão e que era importado de Inglaterra a preços muito elevados, pois só de direitos pagava $1 \$ 200$ réis por arroba. Como não quiseram fazer tal investimento, e por iniciativa de Júlio Pimentel, assinaram um contrato com o Conde do Farrobo ${ }^{62}$, proprietário da Fábrica de Produtos Químicos da Verdelha, que passou a produzir a soda e a fornecê-la para a fábrica do sabão, o que se traduziu numa considerável economia. O Conde do Farrobo convidou Pimentel para ficar também com a inspeção e aconselhamento nesta sua fábrica, ao que ele anuiu, pois os honorários daí decorrentes tornavam-se bem oportunos numa época em que os vencimentos do Estado se achavam em grande atraso e em que as notas do banco em que se faziam os pagamentos estavam fortemente depreciadas por causa da crise financeira de 1846.

Entretanto, o país estava de novo mergulhado na guerra civil, a Guerra da Patuleia, que durou de outubro de 1846 a junho de 1847. Oliveira Pimentel manteve-se à margem do conflito, não querendo envolver-se numa luta que agora se travava dentro do campo liberal e não concordando com a decisão da direção dos Setembristas, sua área política, que, para enfrentar o exército cartista, tinha estabelecido uma aliança contra-natura com forças miguelistas.

Enquanto as escolas se não abriam, passava a maior parte dos dias no laboratório de Química da Casa da Moeda, instituição que tinha posto o seu laboratório à disposição da Escola Politécnica, na sequência do incêndio de grandes proporções que tinha reduzido a escombros em abril de 1843 o edifício do Monte Olivete. Desenvolvia então a pesquisa sobre o fabrico do sabão, tentando descobrir um meio fácil de branquear o óleo de palma. Ao ter a ideia de separar a parte líquida da parte sólida pela cristalização e pressão, conseguiu obter a palmina com suficiente consistência para fabricar velas. Chegou a obter privilégio para a fabricação de velas com a substância extraída do óleo da palma, mas o Conde do Farrobo, que tinha uma fábrica de estearina, propôs-lhe a compra da patente, com o que concordou por não se sentir então disposto a entrar na carreira industrial. Entre as condições do contrato que assinou figurava a obrigação de obter um

${ }^{62} \mathrm{O} 1 .^{\circ}$ Conde do Farrobo, e 2. ${ }^{\circ}$ Barão de Quintela, Joaquim Pedro Quintela (1801-1869), foi um importante capitalista com múltiplos negócios, proprietário fundiário, grande mecenas e um homem dedicado à causa liberal. 
processo para o branqueamento económico da palmina. Com o objetivo de desenvolver o domínio dessa técnica, resolveu voltar a França e a Inglaterra, o que se concretizou no mês de julho de $1848^{63}$, obtida licença para sair até ao fim das férias sem prejuízo dos vencimentos, licença que foi passada atendendo a que desta viagem devia resultar «não só proveito ao supplicante alargando a esphera dos seus conhecimentos scientificos, mas igualmente utilidade immediata ao Estabelecimento a que pertence» ${ }^{64}$.

A partir de 1848, a sua ação vai distribuir-se pela docência (como professor, cedo tratou de escrever um manual atualizado e completo para as aulas que lecionava na Escola Politécnica ${ }^{65}$, no qual incorporou os conhecimentos adquiridos nos cursos que frequentou lá fora), pela investigação no laboratório, pelas inspeções na fábrica do sabão (que abandonou na Primavera de 1851, por grave desinteligência com os contratadores do tabaco, pondo fim à sua cooperação) e na da Verdelha. Foi um período de intensa atividade científica, em muitos casos diretamente ligada ao mundo económico e social.

Para além do fabrico do sabão, da soda e das velas, interessou-se também pela fabricação do papel, tendo chegado a empregar com ótimo resultado a parte filamentosa das piteiras (Agave e Fourcroya) para essa fabricação ${ }^{66}$. Teve também uma experiência de envolvimento direto na atividade industrial, entrando na Sociedade Geral de Produtos Químicos, fundada pela companhia do Crédito Móvel Português, que estabeleceu na Póvoa (hoje Póvoa de Santa Iria) em 1859 uma fábrica de produtos químicos, conhecida como "Fábrica da Póvoa", de que era diretor. A intenção da referida empresa era fornecer o mercado com produtos químicos de melhor qualidade e de mais baixo preço,

${ }^{63}$ Esta viagem decorre num momento muito conturbado da história francesa, o da Revolução de 1848. Ao desembarcar em Southampton no dia 4 de julho, logo teve a notícia da Revolução Socialista de Paris, o que o levou a adiar a partida para esta cidade onde só chegou no dia 17, data em que a revolução já estava jugulada.

${ }^{64}$ Licença concedida «para poder ir a Londres e Paris com o fim de fazer certas investigações sobre alguns processos de chimica industrial». I. B. U. C. - Fundo Visconde de Vila Maior: "Cópia autenticada do Decreto de 25 de Maio de 1848".

${ }^{65}$ Júlio Máximo de Oliveira Pimentel, Lições de chymica geral, e suas principaes applicações, 3 vols., Lisboa: Imprensa Nacional, 1850-1852.

${ }^{66}$ Cf. Julio A. Henriques, "Visconde de Villa Maior", cit., p. XII. 
mas a fábrica sentiu dificuldades desde o início, sendo a sociedade dissolvida em $1862^{67}$.

A segunda metade do século XIX foi um tempo de crise para a vitivinicultura portuguesa sobretudo devido às doenças da videira, como o oídio, o míldio e, principalmente, a filoxera. Mas esse tempo de crise criou também uma oportunidade de renovação nos sistemas de cultivo $^{68}$.Em 1866, Vila Maior foi encarregado, juntamente com António Augusto de Aguiar e João Inácio Ferreira Lapa, de fazer uma avaliação da situação dos centros vinícolas do país e dos processos de produção por eles adoptados ${ }^{69}$. As averiguações então conduzidas levaram-no a perceber a importância deste setor da nossa agricultura, vindo a dedicar-se daí em diante de forma particular ao estudo da viticultura, ampelografia e enologia, visando introduzir os saberes mais recentes na produção vinícola ${ }^{70}$ e simultaneamente desenvolver a investigação sobre a vinha e as castas das uvas através da instalação de uma escola ampelográfica no Jardim Botânico da Universidade ${ }^{71}$. Em 1873 integrou a delegação de Coimbra da primeira Comissão encarregada de estudar a filoxera em Portugal $^{72}$ e em 1878 foi nomeado presidente

${ }^{67}$ Sobre esta fábrica, veja-se Isabel Cruz, Das vantagens de não ser precioso: aspectos da exploração e uso do cobre em Portugal (1789-1889). Centro Interdisciplinar da Universidade de Lisboa. Obra disponível em http://www.triplov.com/ isabel_cruz/cobre/minas1.html.

${ }^{68}$ Ver Gaspar Martins Pereira, "Crises e renovação da viticultura duriense na segunda metade do século XIX”, in José Vicente Serrão et al. (coord.), Desenvolvimento económico e social ... cit., p. 115-131.

${ }^{69}$ Comissão que redigiu a Memoria sobre os processos de vinificação empregados nos principaes centros vinhateiros do reino, Lisboa: Imprensa Nacional, 1867-1868.

${ }^{70}$ Entre outras, escreveu as seguintes obras sobre este tema: Tratado de vinificação para vinhos genuinos, 2 vols., Lisboa: Tip. da Academia Real das Sciencias, 1868-1869; Ampelographia e oenologia do paiz vinhateiro do Douro, Lisboa: Imprensa Nacional, 1870; Manual de viticultura practica, Coimbra: Imprensa da Universidade, 1875.

${ }^{71} \mathrm{Cf}$. Joaquim Augusto Simões de Carvalho, Memoria historica da Faculdade de Philosophia, Coimbra: Imprensa da Universidade, 1872, p. 245.

${ }^{72}$ A Comissão Central, encarregada de estudar o problema da filoxera, era presidida pelo conselheiro Rodrigo de Morais Soares. Tinha sede em Lisboa e criou duas delegações, uma no Porto e outra em Coimbra, esta dirigida pelo Visconde de Vila Maior. Ver Gaspar Martins Pereira, A produção de um espaço regional o Alto Douro no tempo da filoxera, Porto, 1989, Sep. Revista da Faculdade de Letras. II série, vol. VI, p. 322. 
da Comissão de Estudo e Tratamento das Vinhas do Douro, com sede no Porto, mas pediu escusa do lugar, «por motivos de serviço publico». Neste mesmo ano, as suas publicações sobre a cultura da vinha e o seu empenho na causa da eliminação da filoxera valeram-lhe a atribuição de Medalha de Ouro por parte da Société des Agriculteurs de France ${ }^{73}$.

Igual cuidado com a evolução económica do país ditou a elaboração de um estudo sobre a produção da seda no distrito de Bragança (A sericicultura no districto de Bragança, principalmente no concelho de Moncorvo), publicado em $1864^{74}$. Esse estudo respondia ao interesse, estatal e particular, em fazer, no contexto de uma política industrial, o levantamento dos recursos naturais com vista a diminuir o peso das importações de matérias-primas, pois entre esses recursos estava a produção de amoreiras e a criação do bicho-da-seda para a sequente manufatura da seda ${ }^{75}$. Este estudo, além do mais, era-lhe caro por fomentar o desenvolvimento económico da sua terra natal.

A vontade de levar Portugal a equiparar-se às nações mais avançadas, aliada à sua curiosidade científica que abrangia também a Meteorologia, assim como o amor pela sua vila de Moncorvo, onde gozava «os seus ocios campestres», vai impeli-lo a criar na vila nos anos sessenta um posto meteorológico que se fica a corresponder regularmente com o Observatório Meteorológico do Infante D. Luís de Lisboa ${ }^{76}$.

\section{Pareceres e publicações}

Por meados do século ocupou-se com a análise de águas minerais e termais, como as das Caldas da Rainha em 1849, as de Moura no Alentejo em 1850, as do Gerês em Setembro do mesmo ano, as das águas sulfuradas das Caldas da Rainha em 1850 e de novo em 1859,

${ }^{73}$ I. B. U. C. - Fundo Visconde de Vila Maior: "Carta da Société des Agriculteurs de France (3 Novembre 1878)".

${ }^{74}$ Obra referida por Francisco Manuel Alves (Reitor de Baçal), Memorias arqueologico-historicas do distrito de Bragança, tomo VII, Os notaveis, cit., p. 408.

${ }^{75}$ Cf. Ana Maria Cardoso de Matos, "Sociedades e associações industriais oitocentistas: projectos e acções de divulgação técnica e incentivos à actividade empresarial", in Análise Social, vol. XXXI (136-137), 1996, p. 402.

${ }^{76}$ Diario Official do Imperio do Brasil, n. ${ }^{\circ}$ 96, 1 de Maio de 1864. 
as de São João do Deserto em Aljustrel em $1851^{77}$, as da Bica do Sapato em Lisboa em 1853. Neste mesmo ano fez análises sobre as águas potáveis de Lisboa e, também, e mais especificamente, sobre as águas da Fonte de Penabuquel, situada na Alfama. Em 1859 analisou as águas termais dos Banhos de São Paulo, a pedido da Santa Casa da Misericórdia de Lisboa, numa altura em que esta instituição procedia a obras no estabelecimento dos banhos. Satisfazendo ao solicitado pela Câmara de Chaves, analisou em 1863 as águas das Caldas de Chaves, de Vilarelho da Raia e de Vidago. Deu conta do resultado destas análises em publicações, sobretudo em memórias apresentadas à Academia das Ciências. As análises técnicas das águas termais são por vezes acompanhadas por uma apreciação das condições sanitárias das termas, que não é muito favorável, sobretudo no que se refere aos banhos dos doentes pobres.

É também consultado, por esta época, sobre o melhor sistema a adotar para fazer o encanamento da água potável, obras em curso em municípios como o de Évora que, em julho de 1852, procede à reparação do antigo Aqueduto da Água da Prata, ou o de Chaves que, em março de 1864, está a tratar de consertar o aqueduto de pedra que conduzia a água da Serra do Bustelo para a vila. Aconselha, neste último caso, para o revestimento da canalização, a adoção de tubos de ferro betumado, em vez de folha de zinco. Por sua vez, o Governo Civil de Lisboa pede em 1851 parecer sobre a proposta de renovação dos letreiros indicativos das ruas da capital por meio de lâminas de alfalto (parecer que é favorável) e a Câmara Municipal de Lisboa parecer sobre as fábricas insalubres ${ }^{78}$.

Aproveitando a sua estada em Paris por ocasião da Exposição Universal de 1855, o Ministério da Marinha e Ultramar pede-lhe que averigue o verdadeiro processo químico para se conseguir a branqueação

${ }^{77}$ A análise das águas de Moura foi feita a pedido do Duque de Palmela, Pedro de Sousa Holstein, e a análise das águas de São João do Deserto a pedido do Dr. Bernardino António Gomes, médico da real câmara, lente da Escola Médico-Cirúrgica de Lisboa e diretor do Hospital da Marinha. A análise das águas do Gerês foi feita enquanto passava férias em Trás-os-Montes.

${ }^{78}$ I. B. U. C. - Fundo Visconde de Vila Maior: "Carta de Ignacio Fiel Gomes Ramalho, Presidente da Câmara Municipal de Évora de 26 de Julho de 1852"; "Ofício da Câmara Municipal de Chaves de 31 de Março de 1864"; "Ofício do Governo Civil de Lisboa de 20 de Septembro de 1851"; "Ofício da Câmara Municipal de Lisboa de 18 de Julho de 1851". 
de tecidos como as lonas - que eram necessárias ao Arsenal da Marinha para fazer macas - sem que fiquem danificados, processo a ser aplicado na Cordoaria Nacional ${ }^{79}$.

Manteve também uma colaboração importante com o Conselho Ultramarino, organismo que sob a presidência de Sá da Bandeira se empenhou na avaliação dos produtos coloniais, na sua utilização na indústria e no comércio e, simultaneamente, no desenvolvimento das colónias. Redigiu pareceres e efetuou análises científicas e técnicas, entre as quais:

- a análise de amostras de produtos vulcânicos da ilha do Fogo formados pela erupção de 1847, análise que evidenciou, entre outros sais, a presença de sulfato de soda, o que o levou a afirmar: «A producção do sulfato de soda artificial é uma das mais vastas que hoje occupa muitos milhares de trabalhadores, muitos capitaes na Europa. Se a natureza se encarregasse de formar este sal em grande escala e em boas e economicas condições, pelas suas proprias forças [...] o paiz que tivesse a fortuna de possuir essa fabrica natural alcançaria uma importancea incalculavel» ${ }^{80}$;

-o estudo químico do mineral colhido na nitreira da ilha Brava, concluindo que se tratava de salitre (cuja riqueza era de $83,77 \%$ de nitro puro), acrescentando: «Se as condições do local se prestassem à exploração, esta incontestavelmente offereceria vantagem e facultaria occupação a alguns braços d'aquelle desgraçado archipelago [de Cabo Verde] de cuja prosperidade tão pouco se tem cuidado» ${ }^{81 ;}$

- a análise da água dos poços da Vila e da Matiota da ilha de São Vicente ${ }^{82}$

${ }^{79}$ I. B. U. C. - Fundo Visconde de Vila Maior: "Cópia autenticada do ofício do Ministério da Marinha e Ultramar de 19 de Outubro de 1855".

${ }^{80}$ I. B. U. C. - Fundo Visconde de Vila Maior: "Minuta do parecer enviado em resposta ao ofício do Conselho Ultramarino de 18 de Janeiro de 1856".

${ }^{81}$ I. B. U. C. - Fundo Visconde de Vila Maior: "Minuta do parecer enviado em resposta ao ofício do Conselho Ultramarino de 12 de Setembro de 1856".

${ }^{82}$ I. B. U. C. - Fundo Visconde de Vila Maior: "Minuta do parecer em resposta ao ofício da Secretaria d' Estado dos Negocios da Marinha e Ultramar de 14 de Janeiro de 1857». 
- um parecer sobre a conveniência de instalar um laboratório e uma fábrica na costa ocidental africana, proposta do químico francês Langlois de Chalange ${ }^{83}$.

Em 1862, numa carta dirigida a Mendes Leal, então ministro da Marinha e Ultramar, em que dava conta da necessidade de desenvolver a produção de algodão nas colónias, principalmente em Angola, - momento em que a indústria têxtil, sobretudo a inglesa, conhecia grande carência no fornecimento de algodão por causa da Guerra da Secessão norte-americana - asseverava, sintetizando o seu pensamento sobre a questão colonial: «a prosperidade de Portugal e o seu engrandecimento depende em grande do aproveitamento das nossas extensas possessões e da nossa vida maritima. Já que a Providencea collocou em nosso poder tão vastos territorios não podemos nem devemos consentir que elles fiquem extranhos ao progresso do Mundo [...]. No caminho que as coizas tomam a perda de um dia é irreparavel, e as outras nações podem tomar-nos conta do nosso desleixo» ${ }^{84}$.

Autor de uma vasta bibliografia - como sublinhou o doutor António Cândido Ribeiro da Costa: «O catalogo das suas obras é um prodigio bibliographico inverosimil num paiz de indolentes, enervado pelo sol e esterilizado pela politica. São mais os livros uteis, devidos á sua penna, que as veneras e gran-cruzes, que lhe exornavam o peito numa constellação vistosa! ${ }^{85}$-, dela constam obras sobre as temáticas mais diferenciadas. De facto, se não são poucas as condecorações que lhe foram concedidas - fidalgo-cavaleiro da Casa Real, do Conselho de Sua Majestade, cavaleiro da Ordem de Torre e Espada do Valor, Lealdade e Mérito, e da Ordem de S. Bento de Aviz, comendador da Ordem de Cristo, da Ordem de Nossa Senhora da Conceição de Vila Viçosa, e da Ordem de Santiago do Mérito Científico, Literário e Artístico, grã-cruz da Ordem de Carlos III de Espanha, oficial, e depois comendador, da Legião de Honra de França, oficial da Instrução Pública Francesa, grande dignatário da Ordem da Rosa do Brasil, comendador da Ordem de Leopoldo I da Bélgica, e da Ordem de S. Maurício e S. Lázaro de

${ }^{83}$ I. B. U. C. - Fundo Visconde de Vila Maior: "Minuta do parecer de 12 de Maio de 1856 enviado ao Conselho Ultramarino".

${ }^{84}$ I. B. U. C. - Fundo Visconde de Vila Maior: "Minuta de Carta enviada a Mendes Leal em 17 de Agosto de 1862".

${ }^{85}$ Antonio Candido, "[Visconde de Vila Maior]”, cit., p. V. 
Itália -, também o não são as suas publicações, os livros, e os artigos, muitos deles saídos sob a chancela da Academia Real das Ciências de Lisboa, nas Memorias, nos Annaes das Sciencias e Lettras e nas Actas das Sessões, mas também em revistas como o Archivo Universal, a Revista Contemporanea de Portugal e Brazil, a Revista Universal Lisbonense, o Archivo Rural, o Jornal de Horticultura Pratica ${ }^{86}$, ou a Gazeta Medica de Lisboa.

Do seu campo científico, a Química, dimanam, como é natural, os seus principais trabalhos, mas a sua produção é multifacetada. Se muito dissertou sobre aspetos técnicos e científicos da vinha, também soube tratar o Douro e a sua paisagem vinhateira como protagonistas de uma apreciável obra literária ${ }^{87}$, na qual descreve o troço do rio entre Barca de Alva e o Porto sob a forma de impressões de viagem. O gosto pela narrativa, aliado à exigência da salvaguarda da memória, fazem-no compor uma notícia histórica sobre a Universidade ${ }^{88}$, notícias biográficas e biografias ${ }^{89}$, com destaque para a de seu tio, o General Claudino Pimentel ${ }^{90}$.

${ }^{86} \mathrm{O}$ diretor desta revista, Duarte de Oliveira Junior, dedica o volume XVI, de 1885, «Á memoria do Visconde de Villa Maior preclarissimo oenologo e muito distincto collaborador do "Jornal de Horticultura Pratica"».

${ }^{87} \mathrm{O}$ Douro illustrado: album do Rio Douro e paiz vinhateiro: introdução historica e descriptiva, Porto: Magalhães \& Moniz, 1876.

${ }^{88}$ Exposição succinta da organisação actual da Universidade de Coimbra precedida de uma breve noticia historica d' este estabelecimento, Coimbra: Imprensa da Universidade, 1878.

${ }^{89}$ Sobre Luís da Silva Mousinho de Albuquerque: Elogio historico do socio effectivo Luiz da Silva Mousinho d'Albuquerque: recitado na sessão publica da Academia Real das Sciencias ... / pelo socio Julio Maximo de Oliveira Pimentel, Lisboa: Tip. da Academia Real das Sciencias, 1856. Sobre o Barão de Thenard: "Morte do senhor barão Thenard", in Annaes das Sciencias e Lettras, Lisboa: Academia Real das Sciencias, Tomo I, Junho 1857, p. 246. Sobre Joaquim António da Silva: "Joaquim Antonio da Silva", in Revista Contemporanea de Portugal e Brazil, Lisboa: Typ. da Sociedade Typographica Franco-Portugueza, segundo anno, 1860, p. 147-156. Sobre Passos Manuel: Manuel da Silva Passos: noticia biographica, Lisboa: J. G. de Sousa Neves, 1874. Sobre o doutor Coutinho e Vasconcelos: "Dr. Antonio de Carvalho Coutinho e Vasconcellos", in Annuario da Universidade de Coimbra, ano lectivo de 1873 a 1874, Coimbra: Universidade de Coimbra, 1874, p. 18.

${ }^{90}$ Memorial biographico de um militar illustre, o General Claudino Pimentel, Prólogo de Latino Coelho, Lisboa: Imprensa Nacional, 1884. 
Estudos químicos vão saindo ao longo da década de 1850 , sobre a matéria gorda das sementes do brindoeiro e da mafurra, sobre as sementes do amendoim, sobre a produção do sulfato de soda no vulcão da ilha do Fogo, a viciação do ar atmosférico, o óleo de rícino, o alumínio, a faculdade fertilizante das dejeções animais, entre outros ${ }^{91}$. Este último estudo conheceu uma aplicação prática, pois na Exposição de 1857, organizada pela Sociedade Agrícola do Porto, Oliveira Pimentel recebeu uma Menção Honrosa pela apresentação que fez de "estrume dos excrementos humanos tornado inodoro pela cal e carvão" "92.

Estes textos dirigiam-se a cientistas, mas, como considerava que a «gerencia das couzas scientificas, o governo nas sciencias, pertencem incontestavelmente aos sabios; mas o publico, a communidade tem o indisputavel direito de conhecer e comprehender o que os sabios teem feito em seu beneficio» pois «a sciencia mysteriosa, hermetica, occulta e impenetravel perdeu já todo o seu prestigio $»^{93}$, preocupou-se,

91 "Nota sobre a existencia de um novo acido gordo encontrado no sebo do brindão", in Annaes das Sciencias e Lettras, Lisboa: Academia das Sciencias, Tomo I, Março 1857, p. 1-8; "Rectificação da formula do acido solido do sebo do brindão", in Annaes das Sciencias e Lettras. Tomo I, Agosto 1857, p. 348-353; "Note sur les acides gras du brindão de Goa", obra referida em Os Fastos de Publio Ovidio Nasão ... cit., tomo I, p. CXLI; Estudo chymico das sementes do amendobi (arachis hypogea): offerecido á Academia Real das Sciencias de Lisboa. [Lisboa: s. n.], 1853; "A producção do sulfato de soda no volcão da ilha do Fogo no archipelago de Cabo-Verde", in Annaes das Sciencias e Lettras, tomo I, Março 1857, p. 9-20; "Relatorio sobre o estudo chimico do oleo de ricino e alcool caprylico feito por Mr Jules Bouis", in Annaes das Sciencias e Lettras, tomo I, Abril 1857, p. 70-79; "Nota sobre a faculdade fertilisante das dejecções animaes tornadas inodoras pelos meios chimicos", in Annaes das Sciencias e Lettras, tomo I, Junho 1857, p. 197-203; “Novo processo de panificação do Senhor Mége-Mouriés", in Annaes das Sciencias e Lettras, tomo I, Julho 1857, p. 257-276; "Noticias scientificas: o aluminio", in Annaes das Sciencias e Lettras, tomo I, Abril 1857, p. 80-100; "Revista dos trabalhos chimicos no corrente anno de 1857", in Annaes das Sciencias e Lettras, tomo I, p. 139-158, 212-221, 277-284, 354-356, 390-410, 469-479, 542-552, 590-600; "Revista dos trabalhos chimicos em 1858”, in Annaes das Sciencias e Lettras, tomo I, p. 725-741, tomo II, p. 35-43, 77-97, 156-162 e 308-315. E, em colaboração com Joaquim Antonio da Silva, "Estudos sobre a viciação do ar athmospherico", in Annaes das Sciencias e Lettras, Lisboa: Academia Real das Sciencias, tomo I, Maio 1857, p. 119-138.

${ }^{92}$ I. B. U. C. - Fundo Visconde de Vila Maior: "Diploma de Menção Honrosa. Exposição de 1857. Sociedade Agricola do Porto. 15 de Julho de 1857".

${ }^{93}$ J. Pimentel, "Palestra scientifica", cit., p. 128. 
numa atitude que é comum a muitos intelectuais da época, em escrever também para um público mais alargado, junto de quem desejava difundir as mais recentes descobertas da ciência química aplicada à indústria. Assim vão surgindo, com regularidade, artigos sobre o ácido sulfúrico, o alumínio, as cores minerais, o lápis, as louças e produtos cerâmicos, o papel, a soda, a tinturaria, os tira-nódoas e o sabão, os vidros e os cristais, um novo processo de panificação, sobre a vinha e viticultura, além de palestras de divulgação científica genérica ${ }^{94}$.

Muitos dos trabalhos que publicou refletem uma nova aquisição de conhecimentos, pois teve oportunidade de voltar a instruir-se em Paris, quando, como já adiantei, foi nomeado vogal da Comissão Central da Exposição de Paris de 1855 assim como da Comissão de Estudo ${ }^{95}$,

94 "Acido sulphurico", in Archivo Universal, 2. vol., Lisboa: Typographia Universal. 1. ${ }^{\circ}$ anno, 1859. 2. ${ }^{\text {a }}$ serie, n. ${ }^{\circ}$ 5, 1 Agosto, p. 65-67, n. ${ }^{\circ}$ 6, 8 Agosto, p. 83-84. "Aluminio", in Archivo Universal, Lisboa: Typographia de J. V. P. da Silva, 3. ${ }^{\circ}$ vol., 1860, p. 72-74. "Cores mineraes", in Archivo Universal, 2. vol., n. ${ }^{\circ}$, 11 Julho 1859 , p. 20-21, n. ${ }^{\circ} 3$, 18 Julho 1859, p. 38-39, n. ${ }^{\circ} 4$, 25 Julho 1859 , p. 51-53. "Dos esmaltes, e da pintura encaustica entre os antigos", in Os Fastos de Publio Ovidio Nasão ..., cit., tomo II, parte II, p. 351-364. "Lapis", in Archivo Universal, 3. ${ }^{\circ}$ vol., 1860, p. 84. "Louças e productos ceramicos", in Archivo Universal, 1..$^{\circ}$ anno, 1859, 1..$^{\mathrm{a}}$ serie, n. ${ }^{\circ} 1,3$ Janeiro, p. 4-5, n. 2,10 Janeiro,

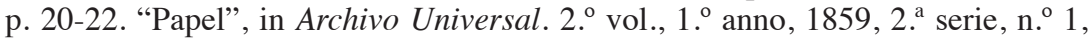
4 Julho, p. 5-8. "Soda", in Archivo Universal, 2. ${ }^{\circ}$ vol., 1. ${ }^{\circ}$ anno, 1859, 2. ${ }^{\text {a }}$ serie, n. 7,15 Agosto, p. 104-106. n. ${ }^{\circ} 8,22$ Agosto, p. 120-121. n. ${ }^{\circ} 10,5$ Setembro, p. 147-148. n. "12, 19 Setembro, p. 181-182. "A tinturaria dos antigos", in Os Fastos..., cit., tomo II, p. 327-340. "Os tira-nodoas e o sabão", in Os Fastos..., cit., p. 318-327. "Vidros e crystaes". in Archivo Universal, 1. . serie, 1. anno, 1859, n. ${ }^{\circ}$ 5, 31 Janeiro, p. 67-68, n. ${ }^{\circ}$ 6, 7 Fevereiro, p. 81-82, n. ${ }^{\circ}$ 7, 11 Fevereiro, p. 98 -99, n. ${ }^{\circ} 8,21$ Fevereiro, p. 114-115, n. ${ }^{\circ}$ 10, 7 Março, p. 146-147, n. 24,13 Junho, p. 370-372, n. 25 , 20 Junho, p. 386-387, n. 26,27 Junho, p. 402-405. "Vinhas americanas", in Jornal de Horticultura Practica, Porto, vol. V, 1874, p. 102-104. "Viticultura: meios de reconstituir os vinhedos nos paizes em que foram destruidos pelo phylloxera", in Jornal de Horticultura Practica, vol. VII, 1876, p. 132-133. "Aquecimento dos vinhos", in Jornal de Horticultura Pratica, vol. XV, 1884, p. 69-74. "Estudos ampelographicos", in Jornal de Horticultura Practica, vol. I, 1870 , p. 33-36, 49-52 e 65-68, vol. II, 1871, p. 61-62, 77-78 e 149-151, vol. III, 1872, p. 11-13. "Palestras scientificas", in Revista Contemporanea de Portugal e Brasil, primeiro anno, 1859, p. 126-131, 188-194, 268-275, 372-377 e 576-582, segundo anno, 1860, p. 425-434, 481-483 e 573-580, terceiro anno, 1861, p. 156-164 e 386-397 (586-597).

${ }^{95}$ Os outros membros desta Comissão eram José Vitorino Damásio, diretor do Instituto Industrial de Lisboa e lente da Academia Politécnica do Porto, Sebastião 
criada na mesma altura, e encarregada de estudar os progressos das diferentes artes e ofícios, de maneira a que as informações colhidas servissem para orientar a indústria nacional.

\section{Trabalho desenvolvido na Exposição Universal de Paris de $\mathbf{1 8 5 5}^{96}$}

O seu labor na Exposição Universal de Paris de 1855 - a qual decorreu entre 15 de maio e 15 de novembro desse ano - desenvolveu-se em dois campos distintos: por um lado, como vogal da Comissão de Estudo, ou seja, na sua qualidade de cientista e de químico, tinha como obrigação instruir-se sobre todas as novidades científicas e tecnológicas em curso, no domínio da Química e da atividade industrial, e delas dar boa nota ${ }^{97}$, por outro, como homem de ação, tinha o encargo de organizar a exposição portuguesa ou, como se diz no decreto que o nomeia em especial para essa tarefa, de "tratar dos arranjos precisos no local destinado naquela Exposição aos productos portuguezes, a fim de que ali sejam convenientemente expostos"98.

A sua participação na Exposição Universal de Paris de 1855 ficou bem documentada, pois Vila Maior elaborou um diário - Diario de viagem em $1855^{99}$ - que começa em 31 de março, data da sua partida

Betâmio de Almeida, lente da Escola Industrial do Porto, João de Andrade Corvo, lente do Instituto Agrícola de Lisboa, José Maria da Ponte e Horta, lente substituto da cadeira de Mecânica da Escola Politécnica e Sebastião José Ribeiro de Sá, chefe da Repartição de Manufaturas no Ministério das Obras Públicas. Ver I. B. U. C. - Fundo Visconde de Vila Maior: "Ofício de 29 de Março de 1855”. Ver também Ruben Andresen Leitão, Diário de viagem a França del-Rei Dom Pedro V, cit., p. 43.

${ }^{96}$ Exposition Universelle des Produits de l'Agriculture, de l'Industrie et des Beaux-Arts de Paris 1855.

${ }^{97}$ Apresentou o seguinte relatório sobre a Exposição: Relatorio sobre a Exposição Universal de Paris: artes chimicas. Parte I. Produto químico de grande fabricação, produtos especiais, cores minerais, produtos steáricos e análogos, aluminia-lápis. Lisboa: Imprensa Nacional, 1857. Parte II. Vidros e cristais, louças e produtos cerâmicos, papel. Lisboa: Imprensa Nacional, 1859. $1855 "$.

${ }^{98}$ I. B. U. C. - Fundo Visconde de Vila Maior: "Ofício de 29 de Março de

${ }^{99}$ Este manuscrito, ilustrado com vários desenhos de aparelhos e de material de laboratório, também se guarda no Instituto Botânico da Universidade de Coimbra e encontra-se em vias de publicação. 
para França, e termina abruptamente em 16 de setembro, data em que se encontrava na Bélgica realizando uma viagem de estudo. $\mathrm{O}$ diário citado contém informações científicas detalhadas de todas as aulas que seguiu e das visitas de estudo que fez, não deixando de dar também informações minuciosas sobre o programa social, referindo os jantares, bailes e galas em que esteve presente.

Para cumprir a missão de que tinha sido encarregado, Júlio Pimentel contactou com especialistas de Química, assistiu a variados cursos e deles deixou notícia pormenorizada, quer do sumário das lições, quer das experiências realizadas nas aulas, assim como dos aparelhos e substâncias utilizadas. Para além das mais recentes descobertas de metais, compostos, ligas, fontes de energia, e sua aplicação à indústria, Pimentel deu também particular atenção à organização dos laboratórios, por exemplo, ao de Henry Sainte-Claire Deville na Escola Normal, ao de Peligot no Conservatório das Artes e Ofícios, ao de Charles-Adolphe Wurtz na Faculdade de Medicina, dos quais fez exata descrição. Entre muitas outras novidades científicas, anotou as recentes descobertas relativas ao alumínio e à sua preparação, ao silício, ao magnésio e aos seus sais, ao crómio e ao manganês, ao mercúrio, aos sais de chumbo, ao alvaiade e seus processos, ao antimónio e à criolite, assim como os trabalhos em curso de Jules Buis com o óleo de rícino e o álcool caprílico.

Fez também uma demorada visita à Escola Politécnica de Paris - vendo as salas de estudo, as camaratas, os anfiteatros, os gabinetes de Física, de Química e de Mineralogia, os laboratórios de Química, as coleções de máquinas e os modelos para o estudo da Mecânica, da Geometria Descritiva e da Arquitetura -, ao Jardim das Plantas onde passou algumas horas visitando a rica coleção do Museu de Mineralogia e à Escola de Pontes e Calçadas, que considerou uma casa boa e elegante, mas sem grandeza nem luxo, com as suas coleções apropriadas ao ensino.

Deslocou-se também a diversas fábricas - a algumas na condição de elemento do Juri da Classe de Química da Exposição ${ }^{100}$-, como

${ }^{100}$ Oliveira Pimentel foi nomeado pela Commissão Imperial para membro do Juri, ficando na X Classe, a dos "Produtos e Artes Químicas", de que era Presidente Jean-Baptiste Dumas. Ficou na secção dos "Tabacos e Ópios" como presidente, na dos "Produtos Químicos" como relator para os produtos de Portugal, Espanha 
a de vidros e cristais de Sèvres, a de borracha de Mr. Gibal, uma de marroquinaria e outra de destilação de madeira em Choisy-le-Roi, uma de chocolate em Noisiel-sur-Marne. Com Jules Buis viu uma fábrica de velas esteáricas e saboaria em La Chapelle.

Depois, numa viagem efetuada com Ponte e Horta e Andrade Corvo, elementos da Comissão de Estudo, e com Casal Ribeiro, voltou à Bélgica visitando de novo a fábrica de John Cockerill em Seraing, à Alemanha onde foi à fábrica de produtos químicos de Carl Clemm-Lennig, em Manheim, e à Escola Politécnica de Karlsruhe. Em Loos e Lille visitou as fábricas do químico e industrial Charles-Frédéric Kuhlmann.

Esta missão na Exposição de Paris de 1855 constituiu assim uma segunda fase de aprendizagem, embora em contexto distinto, pois essa atividade científica desenrolou-se ao mesmo tempo que tratava das suas tarefas no planeamento e execução da exposição dos produtos portugueses no certame.

A vida do Visconde de Vila Maior está estreitamente ligada à implantação e consolidação do Liberalismo em Portugal e o seu pensamento e a sua ação em grande consonância com o ideário liberal. Faz parte de uma elite política e administrativa empenhada na transformação e modernização do país, de molde a colocá-lo a par das nações mais evoluídas da Europa.

Combateu, de armas na mão, pela «defensão e conquista das liberdades» ${ }^{101}$, o que lhe garantiu um lugar no mundo dos vencedores, mas não foi uma figura apostada nas luzes da ribalta política. Embora tivesse estado filiado partidariamente e exercido diversos cargos, quer na Câmara de Lisboa, quer no Parlamento e, mais tarde, na Câmara dos Pares, a sua ação desenvolveu-se sobretudo na área do pensamento, da ciência, da investigação, e da sua aplicação à vida prática, quer no campo da agricultura, onde avulta a preocupação com a vinha e a viticultura, quer no campo da indústria, batalhando pela introdução de novos métodos de fabrico, pela utilização de novos produtos e de novas

e Itália e como relator especial das "Matérias gordas". Informação que consta do manuscrito referido na nota 46.

${ }^{101}$ J. M. Latino Coelho, "Julio Máximo de Oliveira Pimentel”, in Revista Contemporanea de Portugal e Brazil, cit., terceiro anno, 1861, p. 14. 
fontes de energia, pela racionalização da produção, pelo aproveitamento dos recursos, seja no reino, seja nas colónias, destacando-se ainda o seu empenho no incremento do termalismo.

A sua visão do país, feita de largos horizontes, foi construída a partir de uma preparação cuidada. Nomeado professor na Escola Politécnica, não se acomodou à rotina da docência, mas procurou aprender nos grandes centros europeus de investigação científica, junto dos mestres mais conceituados do tempo, assim como em visitas às mais modernas empresas. Era preciso estar a par das novas descobertas da ciência e da tecnologia, das novas forças produtivas, para atualizar o país naquelas matérias de que estava mais carenciado ou que de todo ignorava.

O Visconde de Vila Maior faz parte de uma plêiade de intelectuais que, no século XIX, acreditavam no saber e na instrução como meios de melhorar as condições de vida nas sociedades. A preparação científica que efetuou no estrangeiro foi colocada ao serviço do país, na sua docência e investigação, em pareceres e comissões, em atividades empresariais, nas suas publicações, muitas destinadas ao grande público. É verdade que muitas das inovações técnicas que divulgou e preconizou não passaram do papel, ou tiveram uma aplicação muito restrita ou efémera, sem grandes repercussões num desenvolvimento industrial sustentado, mas, como conclui: «todos os que se esforçam para accrescentar o inventario da riqueza dos estados, quer os seus productos sejam complexos ou singelos, de grande ou modesto valor, todos elles concorrem para o bem geral» ${ }^{102}$.

A sua mundivisão inscreve-se numa ideologia claramente liberal: liberdade de pensamento e liberdade política e económica, livre concorrência das forças sociais, comércio livre. Assim, faz a apologia de uma menor intervenção do Estado, e uma maior autonomia, quer nas universidades, quer nos municípios. Ao analisar o projeto de reforma do Ensino Superior apresentado em 1823 por Mousinho de Albuquerque, concordando embora com o tom geral, critica nele o princípio centralizador, apoiando o restabelecimento de uma autonomia didática e administrativa das universidades, tal como se passava em países mais

${ }^{102}$ J. Pimentel, “A Exposição Internacional de 1862 em Londres”, in Revista Contemporanea de Portugal e Brazil, quarto anno, 1862, p. 481. 
adiantados ${ }^{103}$. Ao sair da presidência da Câmara de Lisboa em 1858, invoca os foros e franquias antigas dos municípios contra as tendências da extrema centralização, a qual diz que "pode ser logica nas monarchias administrativas, mas que repugna á indole do governo representativo ${ }^{104}$. Defende a iniciativa privada no que respeita à atividade industrial, pois considera que estabelecimentos fabris dirigidos, administrados e custeados pelo Governo em concorrência com a indústria particular são sempre "onerosos e prejudiciaes" 105 , devendo o Estado salvaguardar apenas a produção do que reserva como monopólio. Bate-se também por uma livre circulação de bens: "a riqueza das nações cresce com a produção das couzas uteis, esta augmenta com o consumo, e este depende necessariamente da facilidade das relações commerciaes"106. Escreve, assim, em favor de um comércio livre no interior da Península Ibérica, com a supressão das alfândegas entre os dois países, a existência das quais considera só servir à fraude, ao contrabando e à corrupção, sendo um entrave e um obstáculo ao comércio honesto. Advoga ao mesmo tempo a criação de uma liga peninsular para as alfândegas exteriores. É, no entanto, bem claro ao afirmar que esse alvitre de forma alguma se inscreve em qualquer desiderato iberista, ao qual se opõe frontalmente.

Em 1869 toma posse do reitorado da Universidade e passa a residir em Coimbra. Esse facto traz uma viragem nos seus interesses, afastando-se da área da análise química e do universo industrial, e devotando-se agora mais ao estudo da vinha e da viticultura, ao Douro, sua terra natal, assim como à Universidade que dirige, escrevendo sobre a sua história, dinamizando as comemorações do Centenário da Reforma Pombalina em 1872, criando uma escola ampelográfica no Jardim Botânico em colaboração com Júlio Henriques, entre muitas outras iniciativas. Mais longe da atividade económica, esbate-se nele o sentido mais utilitário da ciência. No final da vida considerará que ela prestava,

${ }^{103}$ Visconde de Villa-Maior, "Sciencias moraes e sociaes ...”, cit., vol. XLIV, n. ${ }^{\circ}$ 4, Abril de 1897, p. 199.

${ }^{104}$ I. B. U. C. - Fundo Visconde de Vila Maior: "Minuta da carta de 21 de Dezembro de 1858 dirigida a António Rodrigues Sampaio".

${ }^{105}$ I. B. U. C. - Fundo Visconde de Vila Maior: "Minuta do parecer de 12 de Maio de 1856 enviado ao Conselho Ultramarino".

${ }^{106}$ J. Pimentel, "A Liga das Alfandegas Peninsulares", in Revista Contemporanea de Portugal e Brasil, Lisboa: Typ. da Sociedade Typographica Franco-Portugueza, segundo anno, 1860, p. 69. 
sem dúvida, "poderoso auxílio a todos os ramos da industria humana", mas isso não devia fazer esquecer que "a principal e mais nobre utilidade das sciencias está no seu proprio aperfeiçoamento [...] tendendo a descortinar os mais reconditos segredos da natureza em beneficio da humanidade" 107 .

Ajustam-se bem a Vila Maior as palavras com que ele próprio elogiou Joaquim António da Silva: "animava-o um desejo firme e ardente de trabalhar pela sciencia, pelos progressos da humanidade, pela gloria e bem estar do seu paiz"108.

\section{Bibliografia ativa do Visconde de Vila Maior}

1830-1839

Curso de Chymica Elementar professado na Escola Polytechnica.

Lisboa: na Impressão de Galhardo Irmãos, 1839.

1840-1849

Aagricultura e a chimica, lições sobre a dependencia em que a agricultura racional está da chimica, professadas no Gremio Litterario em 1849 Obra referida em Os Fastos de Publio Ovidio Nasão com traducção em verso portuguez por Antonio Feliciano de Castilho seguidos de copiosas annotações por quasi todos os escriptores portuguezes contemporaneos. Lisboa: Academia Real das Sciencias, 1862, Tomo I, p. CXL.

1850-1859

A producção do sulfato de soda no volcão da ilha do Fogo no archipelago de Cabo-Verde. Annaes das Sciencias e Lettras. Tomo I (Março de 1857), p. 9-20

Acido sulphurico. Archivo Universal. 2. ${ }^{\circ}$ vol. Lisboa: Typographia

Universal. 1. ${ }^{\circ}$ anno (1859). 2. ${ }^{\text {a }}$ serie. N. ${ }^{\circ} 5$ (1 de Agosto), p. 65-67. N. ${ }^{\circ} 6$ (8 de Agosto), p. 83-84.

${ }^{107}$ Visconde de Villa-Maior, "Sciencias moraes e sociaes ...”, cit., vol. XLIV, n. ${ }^{\circ}$, Julho de 1897, p. 400.

${ }^{108}$ J. Pimentel, "Joaquim Antonio da Silva”, cit., p. 156. 
Analyse das águas mineraes das Caldas da Rainha, feita em Julho de 1849, precedida de uma introdução historica. Memorias da Academia Real das Sciencias. Lisboa: Tipographia da Academia

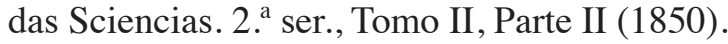

Analyse das aguas mineraes do Gerez.Lisboa: Tipographia da Academia das Sciencias, 1851.

Também saiu nas Memorias da Academia Real das Sciencias. 2. ${ }^{\mathrm{a}}$ ser., Tomo III, Parte II.

As aguas sulfuradas das Caldas da Rainha. Annaes das Sciencias e Lettras. Lisboa: Academia Real das Sciencias. Tomo II, Segundo anno (Maio de 1858), p. 129-155.

As aguas sulfuradas das Caldas da Rainha. Archivo Universal. 1. ${ }^{\text {a }}$ serie, 1. ${ }^{\circ}$ anno. N. ${ }^{\circ} 13$ (28 de Março de 1859), p. 193-194. ‥ 14 (4 de Abril de 1859), p. 209-212. N. 15 (11 de Abril de 1859), p. 225-227. N. ${ }^{\circ} 16$ (18 de Abril de 1859), p. 241-242.

Commissão Portugueza para a Exposição Universal de Paris. $O$ Instituto: jornal scientifico e litterario. Coimbra. Vol. 3. . (1854-1855), p. 250-251. Em colaboração com Marquês de Ficalho et al.

Composition de la stéarine végétale extracté des grames du brindonnier (Brindonia indica). Comptes Rendus de l'Académie des Sciences. Paris. Tomo 44 (1857). Em colaboração com Jules Buis.

Cores mineraes. Archivo Universal. 2. ${ }^{\circ}$ vol. Lisboa: Typographia Universal. 1. ${ }^{\circ}$ anno (1859). 2. ${ }^{\mathrm{a}}$ serie. N..$^{\mathrm{o}} 2$ (11 de Julho), p. 20-21. N. 3 (18 de Julho), p. 38-39. ‥ 4 (25 de Julho), p. 51-53.

Desinvolvimento da superficie activa dos corpos porosos, applicado á construcção das pilhas galvanicas. Actas da Academia Real das Sciencias. Tomo II (1850).

Elogio historico do socio effectivo Luiz da Silva Mousinho d'Albuquerque: recitado na sessão publica da Academia Real das Sciencias... / pelo socio Julio Maximo de Oliveira Pimentel. Lisboa: Tip. da Academia Real das Sciencias, 1856.

Também saiu nas Memorias da Academia Real das Sciencias. 2. ${ }^{\text {a }}$ ser., Tomo II, Parte I.

Estudo chymico das sementes do amendobi (arachis hypogea): offerecido á Academia Real das Sciencias de Lisboa. [Lisboa: s. n.], 1853.

Também saiu nas Memorias da Academia Real das Sciencias. 2. ${ }^{\mathrm{a}}$ ser., Tomo I, Parte I. 
Estudo sobre a viciação do ar athmospherico. Annaes das Sciencias e Lettras. Lisboa: Academia Real das Sciencias. Tomo I (Maio de 1857), p. 119-138. Em colaboração com Joaquim António da Silva. Hygiene publica. Annaes das Sciencias e Lettras. Lisboa: Academia Real das Sciencias. Tomo I (Julho de 1857), p. 285-288; (Setembro de 1857), 411-417; (Outubro de 1857), 454-468; (Novembro de 1857), 514-524; (Dezembro de 1857), 581-589.

Lições de chymica geral, e suas principaes applicações. 3 vols. Lisboa:

Em casa de J. P. Lavado, 1850-1852.

Louças e productos ceramicos. Archivo Universal. Lisboa: Typographia Universal. 1. ${ }^{a}$ serie. $1 .^{\circ}$ anno (1859). N. ${ }^{\circ} 1$ (3 de Janeiro), p. $4-5$. N. 2 (10 de Janeiro), p. 20-22.

Memoria e estudo chymico da agua mineral de S. João do Deserto, em Aljustrel: offerecida á Sociedade Pharmaceutica Lusitana. Lisboa: Imprensa Silviana, 1852.

Memoria sobre hygiene publica, com applicações principalmente á cidade de Lisboa. Archivo Universal. Tomo III.

Morte do senhor barão Thenard. Annaes das Sciencias e Lettras. Lisboa: Academia Real das Sciencias. Tomo I (Junho de 1857), p. 246.

Nota sobre a composição chimica das aguas de Moura no Alemtejo. Actas da Academia Real das Sciencias. Tomo II (1850).

Nota sobre a existencia de um novo acido gordo encontrado no sebo do brindão. Annaes das Sciencias e Lettras. Lisboa: Academia Real das Sciencias. Tomo I (Março de 1857), p. 1-8.

Nota sobre a faculdade fertilisante das dejecções animaes tornadas inodoras pelos meios chimicos. Annaes das Sciencias e Lettras. Lisboa: Academia Real das Sciencias. Tomo I (Junho de 1857), p. 197-203. Noticias scientificas: o aluminio. Annaes das Sciencias e Lettras. Lisboa: Academia Real das Sciencias. Tomo I, (Abril de 1857), p. 80-100.

Nouvelle production de l' acide palmitique par le suif de mafurra. Comptes Rendus de l' Académie des Sciences. Paris. Tomo 41 (1855). Em colaboração com Jules Buis.

Novo estudo sobre as aguas sulphurosas das Caldas da Rainha. Gazeta Medica de Lisboa. (1859).

Novo processo de panificação do Senhor Mége-Mouriés. Annais das Sciencias e Lettras. Lisboa: Academia Real da Sciencias. Tomo I (Julho de 1857), p. 257-276. 
Palestras scientificas. Revista Contemporanea de Portugal e Brasil. Lisboa: Typographia do Futuro. Primeiro anno (1859), p. 126-131, 188-194, 268-275, 372-377 e 576-582. Lisboa: Typ. da Sociedade Typographica Franco-Portugueza. Segundo anno (1860), p. 425-434, 481-483 e 573-580. Terceiro anno (1861), p. 156-164 e 386-397 (586-597). [mal paginado].

Papel. Archivo Universal. 2. ${ }^{\circ}$ vol. Lisboa: Typographia Universal. 1. ${ }^{\circ}$ anno (1859). 2..$^{\mathrm{a}}$ serie. N. ${ }^{\circ} 1$ (4 de Julho), p. 5-8.

Parecer apresentado á Academia Real das Sciencias com as bases que devem servir de thema á discussão publica sobre a reforma e melhoramento da instrucção nacional. 12 de Junho de 1857. Lisboa, 1857. Em colaboração com José Maria Latino Coelho.

Porcellanas. Annaes das Sciencias e Lettras. Lisboa: Academia Real das Sciencias. Tomo II (Junho de 1858), p. 213-234.

Rapport sur les matières grasses présenté au jury de la classe XV à l' Exposition Internationale de 1855. Paris, 1855.

Rectificação da formula do acido solido do sebo do brindão. Annaes das Sciencias e Lettras. Lisboa: Academia Real das Sciencias. Tomo I, Agosto de 1857, p. 348-353

Relatorio sobre a Exposição Universal de Paris: artes chimicas. Parte I. Produto químico de grande fabricação, produtos especiais, cores minerais, produtos steáricos e análogos, aluminia-lápis. Lisboa: Imprensa Nacional, 1857. Parte II. Vidros e cristais, louças e produtos cerâmicos, papel. Lisboa: Imprensa Nacional, 1859.

Relatorio sobre o estudo chimico do oleo de ricino e alcool caprylico feito por Mr Jules Bouis. Annaes das Sciencias e Lettras. Lisboa: Academia Real das Sciencias. Tomo I (Abril de 1857), p. 70-79.

Revista dos trabalhos chimicos no corrente anno de 1857. Annaes das Sciencias e Lettras. Lisboa: Academia Real das Sciencias. Tomo I (Maio de 1857), p. 139-158; (Junho de 1857), p. 212-221; (Julho de 1857), p. 277-284; (Agosto de 1857), p. 354-356; (Setembro de 1857), p. 390-410; (Outubro de 1857), p. 469-479; (Novembro de 1857), p. 542-552; (Dezembro de 1857), p. 590-600.

Revista dos trabalhos chimicos em 1858. Annaes das Sciencias e Letras.

Lisboa: Academia Real das Sciencias. Tomo I (Fevereiro de 1858), p. 725-741. Tomo II (Março de 1858), p. 35-43; (Abril de 1858), p. 77-97; (Maio de 1858), p. 156-162; (Julho de 1858), p. 308-315. 
Soda. Archivo Universal. 2. ${ }^{\circ}$ vol. Lisboa: Typographia Universal. 1. ${ }^{\circ}$ anno (1859). 2. ${ }^{\mathrm{a}}$ serie. N. 7 (15 de Agosto), p. 104-106. N. 8 (22 de Agosto), p. 120-121. N. 10 (5 de Setembro), p. 147-148. N. ${ }^{\circ} 12$ (19 de Setembro), p. 181-182.

Sur la composition du suif de mafurre: communication faite ál'Academie des Sciences de Paris. Paris, 1855. Em colaboração com Jules Buis. Vidros e crystaes. Archivo Universal. 1. ${ }^{\mathrm{a}}$ serie, $1 .^{\circ}$ anno (1859). N. ${ }^{\circ} 5$ (31 de Janeiro), p. 67-68. N. ${ }^{\circ} 6$ (7 de Fevereiro), p. 81-82. N. ${ }^{\circ} 7$ (11 de Fevereiro), p. 98-99. N. 8 (21 de Fevereiro), p. 114-115. N. 10 (7 de Março), p. 146-147. N. ${ }^{\circ} 24$ (13 de Junho), p. 370-372. N.o 25 (20 de Junho), p. 386-387. N. ${ }^{\circ} 26$ (27 de Junho), p. 402-405.

1860-1869

AExposição Internacional de 1862 em Londres. Revista Contemporanea de Portugal e Brasil. Quarto anno (1862), p. 421-428, 476-481 e 520-526.

A Liga das Alfandegas Peninsulares. Revista Contemporanea de Portugal e Brasil. Lisboa: Typ. da Sociedade Typographica Franco-Portugueza. Segundo anno (1860), p. 40-47, 68-80, 137-140 e 286-291.

A sericicultura no districto de Bragança, principalmente no concelho de Moncorvo. (10.12.1864).

Obra referida em ALVES, Francisco Manuel (Reitor de Baçal) - Memorias arqueologico-historicas do distrito de Bragança. Tomo VII. Os notaveis. Porto: Tipografia da Emprêsa Guedes, 1931, p. 408.

A tinturaria dos antigos. Os Fastos de Publio Ovidio Nasão com traducção em verso portuguez por Antonio Feliciano de Castilho seguidos de copiosas annotações por quasi todos os escriptores portuguezes contemporaneos. Lisboa: Academia Real das Sciencias, 1862, p. 327-340.

Aluminio. Archivo Universal. Lisboa: Typographia de J. V. P. da Silva. $3 .^{\circ}$ vol. (1860), p. 72-74.

Dos esmaltes e da pintura encaustica entre os antigos. Os Fastos de Publio Ovidio Nasão com traducção em verso portuguez por Antonio Feliciano de Castilho seguidos de copiosas annotações por quasi todos os escriptores portuguezes contemporaneos. Lisboa: Academia Real das Sciencias, 1862, Tomo II, Parte II, p. 351-364. 
Joaquim Antonio da Silva. Revista Contemporanea de Portugal e Brasil.Lisboa: Typ. da Sociedade Typographica Franco-Portugueza. Segundo anno (1860), p. 147-156.

Lapis. Archivo Universal. Lisboa: Typographia de J. V. P. da Silva. 3. ${ }^{\circ}$ vol. (1860), p. 84.

Memoria sobre os processos de vinificação empregados nos principaes centros vinhateiros do continente do reino, a norte do Douro. Lisboa: Imprensa Nacional, 1867-1868. Em colaboração com João Inácio Ferreira Lapa e António Augusto de Aguiar.

Note sur les acides gras du brindão de Goa.

Obra referida em Os Fastos de Publio Ovidio Nasão com traducção em verso portuguez por Antonio Feliciano de Castilho seguidos de copiosas annotações por quasi todos os escriptores portuguezes contemporaneos. Lisboa: Academia Real das Sciencias, 1862, Tomo I, p. CXLI.

O aluminium: nota scientifica. Annaes das Sciencias e Letras. Lisboa: Academia das Sciencias.

Os tira-nodoas e o sabão. Os Fastos de Publio Ovidio Nasão com traducção em verso portuguez por Antonio Feliciano de Castilho seguidos de copiosas annotações por quasi todos os escriptores portuguezes contemporaneos. Lisboa: Academia Real das Sciencias, 1862, p. 318-327.

Preliminares da ampelographia e oenologia do paiz vinhateiro do Douro. Lisboa: Imprensa Nacional, 1865.

Relatorio do Commissario Regio junto á Commissão Real de Sua Magestade Britannica na Exposição Internacional de 1862 em Londres sôbre a parte administrativa. Lisboa: Imprensa Nacional, 1865.

Relatorio sobre a Classe LXXIII (vinhos, espiritos e cervejas) da Exposição Internacional de 1867. Lisboa: Imprensa Nacional, 1868.

Tratado de vinificação para vinhos genuinos. 2 vols. Lisboa: Typographia da Academia Real das Sciencias, 1868-1869.

Um passeio pela Exposição Industrial do Porto. Revista Contemporanea de Portugal e Brazil. Lisboa: Escriptorio da Revista Contemporanea de Portugal e Brazil. Terceiro anno (1861), p. 251-262.

1870-1879

Allocução recitada pelo Reitor da Universidade na sessão solemne da distribuição dos premios em 16 de Outubro de 1879. Annuario da 
Universidade de Coimbra no anno lectivo de 1879 a 1880. Coimbra: Imprensa da Universidade, 1879, p. IX-XII.

Ampelographia e oenologia do paiz vinhateiro do Douro. Lisboa: Imprensa Nacional, 1870.

Breve noticia da Livraria da Universidade de Coimbra. [S. 1.: s. n., 1877?]. Em colaboração com Bernardo de Serpa Pimentel.

Discurso pronunciado pelo Reitor da Universidade de Coimbra Julio Maximo de Oliveira Pimentel... em 16 de Outubro de 1872 por occasião da festa commemorativa da reforma da mesma universidade em 1872. Coimbra: Imprensa da Universidade, 1872.

Discurso pronunciado pelo Reitor da Universidade de Coimbra Julio Maximo de Oliveira Pimentel visconde de Villa Maior em 16 de Outubro de 1873. Annuario da Universidade de Coimbra no ano lectivo de 1873 a 1874. Coimbra: Imprensa da Universidade, 1875, p. 3-10.

Dr. Antonio de Carvalho Coutinho e Vasconcellos. Annuario da Universidade de Coimbra, ano lectivo de 1873 a 1874. Coimbra: Universidade de Coimbra, 1874, p. 18.

Estudos ampelographicos. Jornal de Horticultura Practica. Porto: Typographia Lusitana. Vol. I (1870), p. 33-36, 49-52 e 65-68. Porto: Typ. da Livraria Nacional. Vol. II (1871), p. 61-62, 77-78 e 149-151. Vol. III (1872), p. 11-13.

Exposição da organização da Universidade de Coimbra. Coimbra: Imprensa da Universidade, 1877.

Exposição succinta da organisação actual da Universidade de Coimbra precedida de uma breve noticia historica d' este estabelecimento. Coimbra: Imprensa da Universidade, 1878.

Manual de viticultura practica. Coimbra: Imprensa da Universidade, 1875.

Manuel da Silva Passos: noticia biographica. Lisboa: J. G. de Sousa Neves, 1874.

Notice historique sur l'Université de Coimbre. [S. 1.: s. n., 1877?].

O Douro illustrado: album do Rio Douro e paiz vinhateiro: introdução historica e descriptiva. Porto: Magalhães \& Moniz, 1876.

Outra edição, trilingue: $O$ Douro illustrado: album do Rio Douro e paiz vinhateiro: introdução historica e descriptiva / Le Douro illustré: album de ce fleuve et de son pays vignoble / The illustrated 
Douro: an album of the river Douro and adjacent wine country. Porto: Livraria Universal de Magalhães \& Moniz, 1876.

Regulamento da Bibliotheca da Universidade de Coimbra. Coimbra: Imprensa da Universidade, 1874.

Relatorio ácêrca da Exposição Universal de Paris em 1878 pelo Commissario Regio. Lisboa: Imprensa Nacional, 1879.

Vinhas americanas. Jornal de Horticultura Practica. Porto. Vol. V (1874), p. 102-104.

Viticultura: meios de reconstituir os vinhedos nos paizes em que foram destruidos pelo phylloxera. Jornal de Horticultura Practica. Porto. Vol. VII (1876), p. 132-133.

1880-1884

Allocução recitada pelo Reitor da Universidade na sessão solemne da distribuição dos premios em 16 de Outubro de 1881. Annuario da Universidade de Coimbra no anno lectivo de 1881 a 1882. Coimbra: Imprensa da Universidade, 1881, p. 19-23.

Allocução recitada pelo Reitor da Universidade na sessão solemne da distribuição dos premios em 16 de Outubro de 1882. Annuario da Universidade de Coimbra no anno lectivo de 1882 a 1883. Coimbra: Imprensa da Universidade, 1882, p. 31-34.

Aquecimento dos vinhos. Jornal de Horticultura Pratica. Vol. XV (1884), p. 69-74.

Memorial biographico de um militar illustre, o General Claudino Pimentel. Prólogo de Latino Coelho. Lisboa: Imprensa Nacional, 1884.

Publicação póstuma

Sciencias moraes e sociaes. Instrucção Superior. O Instituto: jornal scientifico e litterario. Coimbra. Vol. XLIV (1897). N. . 3 (Março), p. 129-136. N. ${ }^{\circ} 4$ (Abril), p. 197-207. N. 5 (Maio), p. 261-268. N. ${ }^{\circ} 6$ (Junho), p. 325-330. N.o 7 (Julho), p. 389-400. N. 8 (Agosto), p. 453-460. N. 9 (Setembro), p. 521-528. N. ${ }^{\circ} 10$ (Outubro), p. 585-594.

Outra publicação

Instrucção Superior. Coimbra: Imprensa da Universidade, 1897. 